\title{
Structural history of the southwestern corner of the Kaapvaal Craton and the adjacent Namaqua realm: new observations and a reappraisal
}

\author{
Wladyslaw Altermann ${ }^{1}$ and Ingo W. Hälbich \\ Department of Geology, University of Stellenbosch, Stellenbosch 7600, Republic of South Africa
}

(Received September 27, 1989; revised and accepted January 28, 1991)

\begin{abstract}
Altermann, W. and Hälbich, I.W., 1991. Structural history of the southwestern corner of the Kaapvaal Craton and the adjacent Namaqua realm: new observations and a reappraisal. Precambrian Res., 52: 133-166.

The rocks along the southwestern margin of the Kaapvaal Craton were deformed up to 7 times during the Early to Middle Proterozoic. The oldest deformation $\mathrm{D}_{1}$ is recorded in the N-S-trending Uitkoms cataclasite of pre-Makganyene age ( $>2.24 \mathrm{Ga}$ ) on the craton, and interpreted as a bedding-parallel thrust. It is assumed to be a branch rising towards the surface from a blind sole thrust that initiated early $N$-S-trending $F_{1}$-folds above it. $D_{2}$ is represented by mainly N-S but also NE-SW and NW-SE-trending imbricates and recumbent fold zones ranging in size from small gravity slumps to large tectonic decollements in Asbesheuwel BIF and the Koegas Subgroup, and is younger than $D_{1}$ or equals $D_{1}$ in age. These structures pre-date the Westerberg dyke-sheet intrusion. $\mathrm{D}_{3}$ south-verging folds and thrusts are the oldest post-Matsap deformations, just less than $2.07-1.88 \mathrm{Ga}$. $\mathrm{D}_{4}$ are upright to east vergent and $\mathrm{N}$-S-trending folds deforming all previous structures. $\mathrm{D}_{4}$ post-dates the Westerberg dyke-sheet and probably reactivates $\mathrm{N}-\mathrm{S}$ folds above the earlier sole thrust during renewed E-W compression. $\mathrm{D}_{5}$, producing the main NW-trending Namaqua structures, is only very feebly developed in the Kheis terrain and absent from the cratonic areas overlain by Olifantshoek and older strata, i.e. NE, E and SE of the Marydale High. Very gentle $D_{6} E-W$ to ENE-WSW folds produce culminations and depressions in all NW-trending older structures. During $\mathrm{D}_{7}$ the NW-SE-trending Doornberg Lineament, an oblique left-lateral wrench, and smaller $\mathrm{N}$-trending faults such as the Westerberg Fault developed. These and similar, but right-lateral faults are the last movements along the rim of the craton and occurred around $1.0 \mathrm{Ga}$.

Multiple folding and thrusting with riebeckite mobilization happened prior to Namaqua events and resulted inter alia in discernable duplication and thickening of the Transvaal Supergroup along the southwestern margin of the Kaapvaal Craton and at least some $130 \mathrm{~km}$ into the craton interior. This complicates stratigraphic correlation as well as true thickness estimates of BIF units in Griqualand West, and affects the model for the environmental evolution of the Ghaap Group. A structural model of thin-skin decoupling at the base of the Transvaal Supergroup and starting in the MiddleEarly Proterozoic is proposed.
\end{abstract}

\section{Introduction}

The Transvaal Basin sediments in Griqualand West, northern Cape Province are bordered by multiply folded orogenic realms of the Namaqua Mobile Belt (Vajner, 1974a) and the Kheis Tectonic Province (Stowe, 1986). Nevertheless, the southwestern margin of the

\footnotetext{
*Present address: Goethering 27a, D-5804 Stein, FRG.
}

Kaapvaal Craton is stated to be "overlain by only slightly deformed Early Proterozoic cover successions" (Stowe, 1986, p. 186). Beukes (1983) correlated parts of the Ghaap Group (Table 1) from north to south across Griqualand West regardless of possible structural complications. This correlation is based mainly on borehole data gathered between Koegas (Westerberg) and Kuruman (Whitebank) (Fig. 1). However, recent work along the 


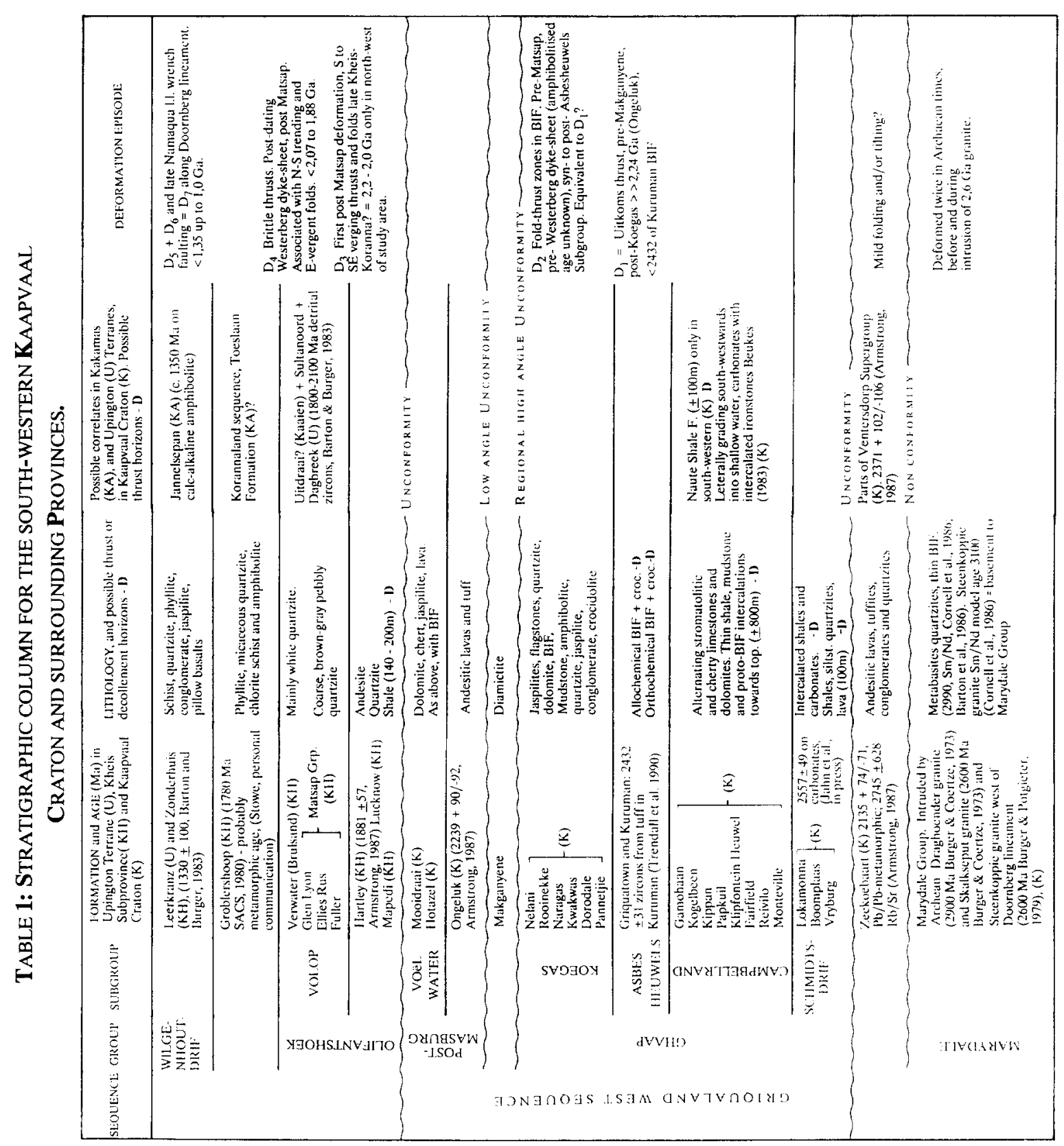


southwestern margin of the Kaapvaal Craton between Prieska and Boegoeberg Dam (Fig. 1) reveals a strong multiple tectonic imprint on Transvaal cover rocks including possible blind thrusts, stacked thrust-sheets and recumbent folds. Some of these structures have now been found as far as Koupoort and Griquatown, up to $130 \mathrm{~km}$ across the craton boundary. Present stratigraphic correlations, especially within the Asbesheuwels Subgroup (Table 1), are therefore questioned.

Detailed structural descriptions are pre-

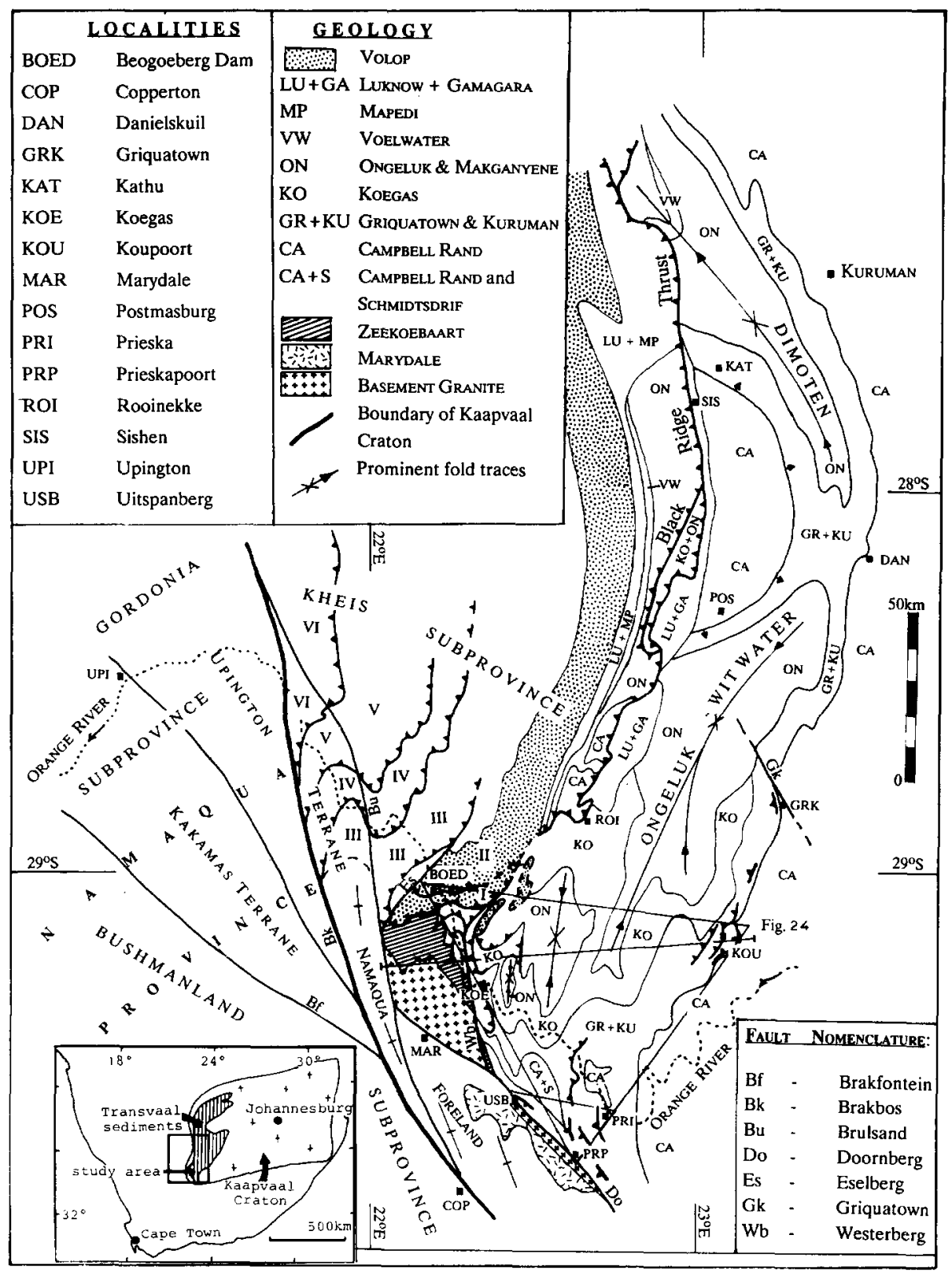

Fig. 1. Location of the study area (between Koupoort, Prieskapoort and Boegoeberg Dam ) along the southwestern margin of the Kaapvaal Craton and of the structural model of Fig. 24. Geology after Vajner (1974), Stowe (1986), Beukes and Smit (1987), modified, and after our own observations. 
sented elsewhere (Altermann and Hälbich, 1990 ). Here we use the essence of that information and present it together with new data to discuss these in the light of the objectives of this paper. This is, to compare the deformational and erosional episodes found in the cover rocks of the craton and correlate them with published information of the surrounding Kheis, Gordonia and Bushmanland sub-provinces. The main new evidence presented is threefold. (a) The first deformation $\left(D_{1}\right)$ on the Kaapvaal Craton pre-dates the Makganyene diamictite and is therefore older than the Ongeluk lava (2.24 Ga). (b) These cataclasites could very well represent the eroded branch of a blind sole thrust. Both were inactive during $D_{2}$ and $D_{3}$, but the sole thrust was reactivated and extended eastwards during $\mathrm{D}_{4}$, producing $F_{4}$ folds in its hanging wall over large areas in Griqualand West with craton-ward convex trends. (c) Evidence of intense folding and thrusting is observed up to the Griquatown Fault.

A wide variety of stratigraphic names exists in the literature for local units and facies changes of the Transvaal Supergroup. Throughout this paper we stick to the stratigraphic column of Beukes and Smit (1987) as expanded to include strata from the subprovinces around the craton (Table 1, Fig. 1).

\section{Geological background}

The Lower Proterozoic I (Vaalian) Transvaal Supergroup of Beukes (1980, 1983), i.e. the Ghaap, the Postmasburg and the Olifantshoek Groups (Table 1) are described in many papers and unpublished M.Sc. and Ph.D. theses of which the most important are by Rogers and Du Toit (1909), Du Toit (1945), Cilliers (1961), Hanekom (1966), Fockema (1967), Vajner (1974a, b) and Beukes (1980, $1983)$.

The age of this sequence is determined by radiometric dating of the associated volcanic rocks. In the Transvaal the Ghaap Group is underlain by the Ventersdorp Supergroup. Judging from stratigraphic relationships, the Ventersdorp appears equivalent to Vajner's (1974a) Zeekoebaart Formation in the southwestern part of the Kaapvaal Craton. However, the Ventersdorp Supergroup dates at 2.7 Ga (Armstrong et al., 1986), while Armstrong (1987) dated the Zeekoebaart Formation at $2135_{-74}^{+71} \mathrm{Ma}$ by the $\mathrm{Pb} / \mathrm{Pb}$ method and at $2745 \pm 628 \mathrm{Ma}$ by $\mathrm{Rb} / \mathrm{Sr}$. Walraven et al. (1982) dated parts of the Zeekoebaart Formation at around $2.2 \mathrm{Ga}$, which is comparable to the more reliable age of the Ongeluk Andesite Formation above the Ghaap Group. However, the Asbesheuwels Subgroup (Kuruman IF) has been dated at $2432 \pm 31 \mathrm{Ma}$ (Trendall et al., 1990) and the Schmidtsdrif Subgroup (lowest Ghaap Group) has been dated by Jahn et al. (1990) at $2557 \pm 49 \mathrm{Ma}$. Therefore, the Zeekoebaart must be of Archaean age.

The Ongeluk Andesite Formation of the Postmasburg Group in Griqualand West has been dated at $2240 \pm 57 \mathrm{Ma}$ (Walraven et al., 1982 ) and at 2239+69 Ma (Armstrong, 1987). The possibly equivalent Hekpoort lavas from the Transvaal sequence have an age of $2224 \pm 21 \mathrm{Ma}$ (SACS, 1980).

The Hartley Formation which forms the lower part of the Olifantshoek Group, has an age of $2070 \pm 90 \mathrm{Ma}$ (SACS, 1980) or $1881 \pm 57$ (Armstrong, 1987) and the Groblershoop Formation lavas which overlie the Olifantshoek Group (Beukes and Smit, 1987) and outcrop in the Kheis Subprovince (Fig. 1) have a minimum age of $1780 \mathrm{Ma}$ (SACS, 1980 ) thought by C.W. Stowe to be metamorphic (pers. commun., 1989). Thus, the Olifantshoek Group is at least between $1.881 \mathrm{Ga}$ and $1.78 \mathrm{Ga}$ old. The Dagbreek Formation underlying parts of the Upington Terrain (Fig. 1 and Table 1) has a maximum age of 1.8 to 2.1 $\mathrm{Ga}$ (U/Pb-detrital zircons-Barton and Burger, 1983) 


\section{TABLE 2: Possible CORRELATION OF STRUCTURAL EVENTS AS PERCEIVED BY VARIOUS AI}

\begin{tabular}{|c|c|c|c|c|c|}
\hline $\begin{array}{l}\text { VAJNER (1974) In Kheis and } \\
\text { Gordonia Subprovinces and } \\
\text { Kaapvaal Craton between } 29^{\circ} \mathrm{S} \\
\text { and } 29^{\circ} 30^{\circ} \text { S, west of } 22^{\circ} 30^{\prime} \mathrm{E}\end{array}$ & $\begin{array}{l}\text { POTGIETER (1982) South of } \\
29^{\circ} 30^{\prime} \text { S and west of } 23^{\circ} \mathrm{E} \text { from } \\
\text { Kaapvaal Craton in to Namaqua } \\
\text { Province (Fig. 1) }\end{array}$ & $\begin{array}{l}\text { THEART (1985) AND } \\
\text { HUMPHREYS et al. }(1988 \mathrm{a}+\mathrm{b}) \\
\text { in Copperton area, Namaqua } \\
\text { Province (Fig. 1). }\end{array}$ & $\begin{array}{l}\text { STOWE (1986), HARRIS (1988) } \\
\text { Upington and Kakamas Terranes } \\
\text { (Fig. 1) }\end{array}$ & $\begin{array}{l}\text { STOWE (1986) } \\
\text { Kheis Subprovince north of } \\
\text { Marydale High (Fig. 1) }\end{array}$ & $\begin{array}{l}\text { SC } \\
\mathrm{Na} \\
\text { por }\end{array}$ \\
\hline
\end{tabular}

Marydale Group, deformed prior

to int rusion of 2,9 and $2,6 \mathrm{Ga}$

granites

Zeekoebaart $\mathrm{Fm}$. resting non-

conformably on $2,6 \mathrm{Ga}$ granite.

Deformed twice prior to the

deposition of the Ghaap Group

NE trending schistosity $=\mathrm{D}_{2}$

in present paper, $\mathrm{N}-\mathrm{S}$ trending

cleavage $=D_{4}$ in present paper

Gravity folding slumps in BIF by subsidence of "intrageo-

syncline" on the craton.

two episodes.
Slump folded BIF (Asbesheuwel

Subgroup)
Open NE-folding, vertical axial planes in Transvaal Supergroup. Considered preMatsap.

$F_{1}$ Sharp hinged. $S_{1}$ axial planar cleavage in Kaaien Group considered Archean by Vajner. Now Sultanaoord-Dagbreek equivalents in domain III (Table 1, Fig. 1) (Stowe 1986)

$F_{2}$ Round hinged, upright, isoclinal. Deforming $F_{1}$ and $S_{1}$ in Gordonia Subprovince (conside red Archean by Vajner because it affects Kaaien and Marydale Groups).

$\mathrm{F}_{3}$ Post Matsap. NNE-plunging axes on Kaapvaal $\mathrm{Cr}$. NE. plunging in Namaqua Foreland and Kheis Subprov. (Fig. 1)
DN horizontal, N-S, open folds, upright, no cleavage, in Zeekoeba art Formation and Griqualand West Sequence. (Also found post Matsap by present authors) e.g. Ongeluk - Witwater syncline (Fig.1)

$\mathrm{DN}+1$. Most intense folding west of Bn (Fig. 1) NW in south, NNE in N. Orientation changing around Marydale High. deforming $\mathrm{SN}+1$. Horizonta axes. Co-axial with $F N+1$, no concomitant foliation.

$\mathrm{DN}+3$. NE-striking, upright, open, zonally developed folds in Namaqua Foreland (Fig. 1).
$\mathrm{NF}_{1} \mathrm{a}$ and $\mathrm{NF}_{1} \mathrm{~b}$ SE and SSW verging isoclines respectively. C. 1,75 Ga and $<1,35 \mathrm{Ga}$ respectively.
$\mathrm{KD}_{1}$ and $\mathrm{KD}_{2} \mathrm{E}$ to $\mathrm{SE}$ verging folds and thrusts.

Tight " $\mathrm{Z}$ "-KF ${ }_{2}$-folds develop

in zones.
$\mathrm{F}_{4}$ NW-alignment of structural elements everywhere, associated with Doornberg Lineament.
$\mathrm{FN}_{1} \mathrm{a}$ and $\mathrm{FN}_{1} \mathrm{~b}$ Both isoclinal, horizontal, co-axial. Produced by west vergent back-folding during east-directed thrusting $<1,3 \mathrm{Ga}$ $=$ age of Areachab $=$ Kaaien $=$ Uitdraai Groups

$\mathrm{FN}_{2}$ NW-trending, upright and SE plunging. Main Namaqua phase.

$\mathrm{FN}_{3} \mathrm{~N}$ to NE-striking, interference, with $\mathrm{FN}_{2}$ to form domes and basins with NW or SE plunging axes.
Only remnants recognisable. Almost totally transformed by $\mathrm{NF}_{2}$

Upington Terrane: $\mathrm{NF}_{2} \mathrm{NW}$ trend, NE-verging tight, main Namaqua phase.

Kakamas Terrane: SW-verging recumbents in a south-westerly zone; reclined, subvertical $\mathrm{NF}_{2}$ isoclines in central zone $(1,2$ to 1,1 Ga)

Pre- $\mathrm{NF}_{3}$ thrusts along Bf (Fig. 1) not related to transpression during late Namaqua dextral shear (Harris, 1988)

$\mathrm{NF}_{3}$ ENE-trending, open, (e.g.

Graafwater synform. - Harris,

1988) refolding $\mathrm{NF}_{2}$ into

"recumbent" and steep zones
$\mathrm{KF}_{3} \mathrm{NNE}$ to $\mathrm{N}$-trending folds in discrete zones. Refolding $\mathbf{K T}_{1}$ and $\mathrm{KT}_{2}$ thrusts.

$\mathrm{KF}_{4}$-open folds at SW-margin of Kheis Subprovince c. 1,2-1,1 Ga. eg. Orange River Synform (Fig. 1)
DN + 4. Doornberg wrench fault zone, left lateral.
$\mathrm{NF}_{4} \mathrm{NW}$-trending monoclines interfering with $\mathrm{NF}_{3}$ antiforms. $\mathrm{NW}$-trending shear zones c. 1,0 $\mathrm{Ga}$ 



\section{IED BY VARIOUS AUTHORS AROUND AND ON THE SOUTH-WESTERN KAAPVAAL CRATON}

\begin{tabular}{|c|c|c|c|}
\hline $\begin{array}{l}\text { IOWE (1986) } \\
\text { leis Subprovince north of } \\
\text { arydale High (Fig. 1) }\end{array}$ & $\begin{array}{l}\text { SCOTT (1987) } \\
\text { Namaqua Foreland - Prieska- } \\
\text { poort to Copperton (Fig. 1) }\end{array}$ & $\begin{array}{l}\text { BEUKES AND SMIT (1987) } \\
\text { Griqualand West Sequence, } \\
\text { east of Kheis Subprovince } \\
\text { (Fig. 1) }\end{array}$ & $\begin{array}{l}\text { COWARD AND POTGIETER } \\
\text { (1983) Kheis, Gordonia and } \\
\text { Bushmanland Subprovinces, } \\
\text { Namaqua Foreland. }\end{array}$ \\
\hline & & & $\begin{array}{l}\text { Marydale Group ( } 2,99 \mathrm{Ga}) \text { folia- } \\
\text { ted before granite intrusion. } \\
\text { Early syntetonic Marydale } \\
\text { granite }(2,6 \mathrm{Ga}) \text { foliated NW-SE }\end{array}$ \\
\hline & & & $\begin{array}{l}\text { Minor folds in Zeekoebaart } \\
\text { Formation uncomformably } \\
\text { overlain by Griqualand West Se- } \\
\text { quence. Several younger clea- } \\
\text { vages destroy older structures in } \\
\text { Seekoebaart Formation. }\end{array}$ \\
\hline
\end{tabular}

\section{PRESENT AUTHORS}

Kaapvaal Craton up to Matsap thrusts,

Marydale High and Doornberg Lineament

(Fig. 1)

Marydale Group (2,99 Ga) folia-

ted before granite intrusion.

Early syntetonic Marydale
granite $(2,6 \mathrm{Ga})$ foliated NW-SE

Minor folds in Zeekoebaar

Formation uncomformably

quence. Several younger clea-

Seekoebaart Formation.

Mild folding in Zeekoebaart Formation prior to erosion and deposition of Griqualand West Sequence. Older foliation(s) with southerly dips deformed by $\mathrm{S}_{4}$; latter dips steeply WNW with down dip lineation.

$D_{1}$ Uitkoms Thrust. $>>2,24 \mathrm{Ga},<2,5 \mathrm{Ga}$. Bedding parallel cataclasites in Koegas Subgroup following limbs of early N-S $\left(\mathrm{F}_{1}\right.$ ?) folds reactivated during $\mathrm{D}_{4}$ by post-humous folding of Ongeluk. Probably branch of sole structure following Vryburg shale horizon. Movement to $\mathrm{E}$

$\bar{D}_{2}$ Recumbent fold zones, thrusts, imbricates, decollements in BIF on all scales. Varying cleavage in BIF-lutites, Movement to SE, E, and NE. Syn- to post-Asbesheuwels Subgroup pre-Westerberg dyke sheet, pre-Magkanyene. Equivalent to or incorporating $\mathrm{D}_{1}$ ?

1 and $\mathrm{KD}_{2} \mathrm{E}$ to $\mathrm{SE}$ verging $s$ and thrusts. it " $\mathrm{Z}$ "- $K F_{2}$-folds develop snes.

NNE to $\mathrm{N}$-trending folds in rete zones. Refolding $\mathrm{KT}_{1}$ $\mathrm{KT}_{2}$ thrusts.

-open folds at SW-margin of is Subprovince c. 1,2-1,1 Ga. range River Synform (Fig. 1).
Black Ridge Thrust Zone. Mo-

vement to $\mathrm{E}$ and $\mathrm{SE}$. (Merging SE-vergent thrusts and imbricawith basal thrust of Matsap in tes $N$ of Uitspanberg. $E$ of study area. Oldest rocks thrust tes N of Uitspanberg, E of are Matsap. Thrust post-dates deformed by $D_{A} \mathrm{~N}-\mathrm{S}$ trending basement granite is equivalent of folds in Boegoeberg Dam area thrusts but back-folded. Age: (Fig. 1) as reinterpreted by Post Hartley $(<2,07-1,88 \mathrm{Ga})$ present authors).
$F_{1}$ NW-trending steep isoclines verging NE. Penetrative axial planar cleavage. $T_{1}$ thrusts along lithological contacts reactivated during $F_{3}$
$F_{2}$ Refolds $F_{1}$ along NE-trending subvertical planes producing elongate interference domes
N-S to NE-SW-trending asymmetric SE-verging folds with varying plunges (refolded by $D_{6}$, present authors) Local axial planar cleavage dipping NW found $\mathrm{N}$ of Prieska

Doornberg Thrust, back-folded into near vertical attitude with down-dip lineations and vertical sheath folds. Situated along and just E of Doornberg-NW-SE Fault. Originally with NE vengence and movement

NW-SE to N-S folds \& crenulation, axial planar cleavage, verging SW in Griqualand West Sequence. NW or SE plunging lineation folded by NW folds in Bushmanland Subprovince.

E-W trending set of folds in Griqualand West Sequence; age relationship to N-S or NE-SW trends in some rocks is uncertain

NW-trending right-Jateral wrenches (or tilted thrusts?) e.g. Copperton Fault. Drags axial planes of just older $\mathrm{NW}$-folds in Bushmanland Subprovince. (Back - folding episode?, present authors )
$D_{3}$ First post-Matsap deformation(s). $S$ to SE vergent near horizontal folds and thrusts in Boegoeberg Dam area. North dipping axial planar cleavage. $<2,07-1,88 \mathrm{Ga}$

$\mathbf{D}_{4}$ Upright to E-vergent folds and limited brittle thrusts trending N-S. Folds deform $\mathrm{D}_{3}$ thrusts. Post humous folding along early N-S $F_{1}$-folds. Post dating Westerberg dyke. Steeply west dipping cleavage. $<2,07-1,88 \mathrm{Ga}$. Some reactivation of $T_{1}-T_{2}$ is possible.

Ds The main Namaqua NW-SE trending NF of Stowe (1986) has not developed in the study area, i.e. east of the Doornberg Lineament and the Westerberg Fault. Shielded by protoMarydale High?

$D_{6}$ E-W to ENE-WSW-trending very open folds producing culminations and depresions in $F_{4}$. Associated with E-W crenulations and vertical cleavage in Volop and Schmidtsdrif strata along northern edge of Marydale High.

D Doornberg Lineament, a major long-lived left-leteral oblique wrench. Westerberg Fault is a smaller branch. Marydale Itigh lifted up by scissor-type movement between both. Between Prieska-Prieskapoort-Uitspanberg produces deflection and re-orientation by drag and transpression of $F_{4}$ and $T_{4}$ in up to $8 \mathrm{~km}$ wide zone of Lineament $\pm 1,0 \mathrm{Ga}$. 



\section{Review of previous structural work}

The tectonic evolution of the Transvaal Supergroup in Griqualand West was discussed by Visser (1944), who recognized up to six thrust planes along which slabs of the Transvaal strata were pushed eastwards onto the craton. However, Visser's (1944) investigations remained unaccepted among most of the later workers.

More recently Beukes and Smit (1987) presented stratigraphic and structural evidence for post-Olifantshoek (1.8-2.1 Ga-Barton and Burger, 1983) thrusting along the northwestern margin of the Kaapvaal Craton. Their Blackridge thrust system (Table 2 and Fig. 1) has been traced intermittently over a distance of $180 \mathrm{~km}$ in a N-S direction and they suggested that the low-angle thrusts accompanied by mylonite zones are related to the KorannaKheis ( 1.8 to $2.2 \mathrm{Ga}$ ) orogeny.

Vajner (1974a) recognized two pre-Matsap deformation episodes affecting the Griqualand West Sequence. The first is gravity folding of BIF by subsidence of the "intrageosyncline" on the craton, and the second is a postconsolidation folding resulting in open fold structures. Post-Matsap $\mathrm{F}_{3}$ are $\mathrm{N}$ - to NEplunging structures with $E$ to $S E$ vergency and $\mathrm{F}_{4}$ produces mainly gentle upright folds with a northwesterly trend. A final overprint of the area was thought to be related to the Doornberg Fault Zone (Fig. 1), which is a major NW-SE-striking tectonic lineament along the southwestern rim of the Kaapvaal Craton. According to Vajner (1974b), the Doornberg Fault Zone is genetically related to the upright, northwest-trending folds. It has a dextral, oblique slip inferred to be produced by anticlockwise rotation of the craton relative to the Namaqua Mobile Belt.

A re-interpretation of Vajner's $F_{1}$ and $F_{2}$ (pre-Matsap) in Kaaien rocks (Table 2), some of which are now known as the Uitdraai Formation, equivalent to the Sultanaoord and Dagbreek Formation (1800-2100 Ma, Barton and Burger, 1983) makes these deformations much younger and probably correlatable with $\mathrm{DN}+1$ and $\mathrm{DN}+2$ (Potgieter, 1981), FN+1 and $\mathrm{FN}+2$ (Theart, 1985) and $\mathrm{NF}_{1}$ and $\mathrm{NF}_{2}$ (Stowe, 1986) and with the Doornberg thrust episode followed by backfolding (Coward and Potgieter, 1983). Vajner's observation on preProterozoic deformations in Archaean Marydale granite and metabasites remain valid (Table 2).

Stowe $(1983,1986)$ described the tectonic frame of the Namaqua Province and the Kheis and Gordonia Subprovinces off the Kaapvaal Craton (Fig. 1 and Table 2). He recognized up to three main folding events $\left(\mathrm{KF}_{1}-\mathrm{KF}_{3}\right)$ in the Kheis Subprovince located north and northwest of our area of investigation. In the younger Namaqua Province to the south and west, Stowe (1986) recognized four folding events $\left(\mathrm{NF}_{1}-\mathrm{NF}_{4}\right)$.

According to Stowe (1986), the $\mathrm{KF}_{1}$ produced $E$ to $S E$-vergent recumbent isoclines and eastward directed thrusting $\sim 1750 \mathrm{Ma}$ ago. The $\mathrm{KF}_{2}$ event resulted in " $\mathrm{Z}$ "-folds and renewed thrusting $<1350 \mathrm{Ma}$ ago and the $\mathrm{KF}_{3}$ produced NNE- to $\mathrm{N}$-trending folds in discrete zones. The $N F_{1}$ is age equivalent to $\mathrm{KF}_{1}-\mathrm{KF}_{2}$ and resulted in SSW to SE-verging isoclines. The $\mathrm{NF}_{2}$-folds are recumbent to isoclinal and may be SW- to NE-verging in different localities. Because $\mathrm{NF}_{2}$ refolded and rotated $\mathrm{KF}_{1}-$ $\mathrm{KF}_{3}$ structures it must be younger than these (1200-1100 Ma ). $\mathrm{NF}_{3}$ resulted in ENE-trending open folds and $\mathrm{NF}_{4}$ in NW-trending shear zones and locally in NW-trending monoclines. The age of $\mathrm{NF}_{4}$ is estimated as $\sim 1000 \mathrm{Ma}$ (Stowe, 1986).

The findings of Theart (1985) and Scott (1987) as well as Humphreys et al. (1988) are based on field work done in part much earlier during the eighties. Their results are based on a high intensity of localized data and an attempt was therefore made to include their conclusions (Table 2). The findings of Coward and Potgieter (1983) (Table 2) which summarize and provide new outlooks are treated further below. 


\section{Structure of the study area}

The area described in the present paper is outlined in Fig. 1. Apart from covering new ground, it includes parts of the Kaapvaal Craton investigated by Vajner (1974a) and parts of the Namaqua Foreland mapped by Potgieter (1981) and is located south of the Griquatown growth fault. The entire Griqualand West Sequence of the Transvaal Supergroup (Table 1 ) is present in the region investigated. The latter rests with a basal conglomerate on the Zeekoebaart Formation. The cratonic basement underlying the Zeekoebaart Formation is exposed in the extreme southwest, bordering the Namaqua Province across the Doornberg Lineament (Fig. 1). The presently accepted boundary of the craton is the Brakbos Fault.

\section{Structural relationships between Prieskapoort, Prieska and Uitspanberg (Fig. 2)}

Coward and Potgieter (1983) described thrusting of two ages in this area. They suggest an older Kheis orogeny (shown by Stowe, 1986, to have two components, $\mathrm{KF}_{1}$ and $\mathrm{KF}_{2}$ in the Kheis Subprovince, Table 2) with thrusting to the SE, that probably occurred around $1.75 \mathrm{Ga}$ ago (Stowe, 1986). A minimum displacement of $120 \mathrm{~km}$ to the south was determined for this episode. According to them, a younger Namaqua episode has folds and thrusts verging NE. Both thrust systems converge between Boegoeberg and Marydale to form a double system along the Doornberg $\mathrm{Li}$ neament farther south (Fig. 1). This was then steepened along NW-trending back-folds that

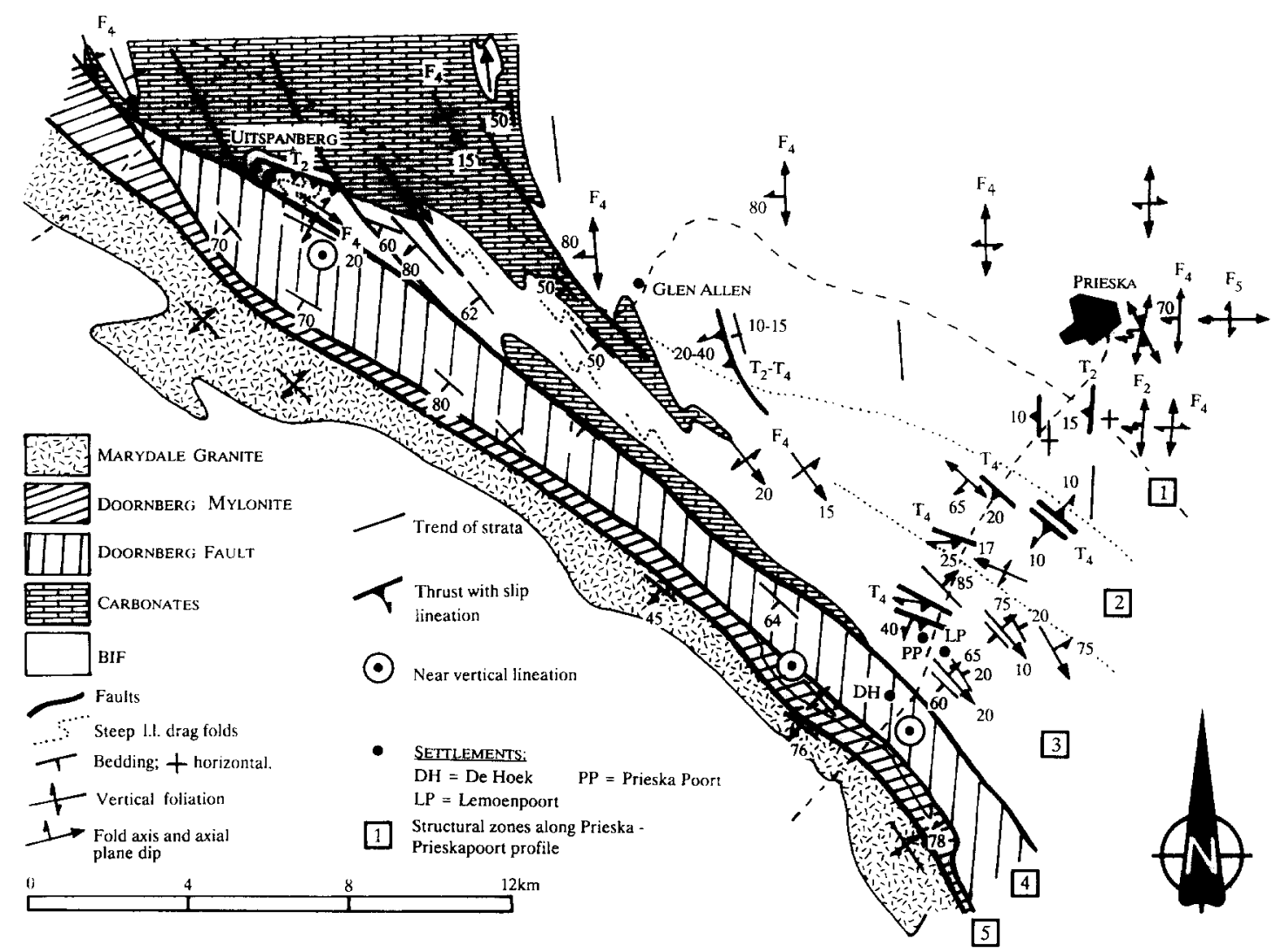

Fig. 2. Geological map of the Prieska-Prieskapoort-Uitspanberg area. See Figs. 1 and 7 for location. Dotted lines separate domains mentioned in text. 


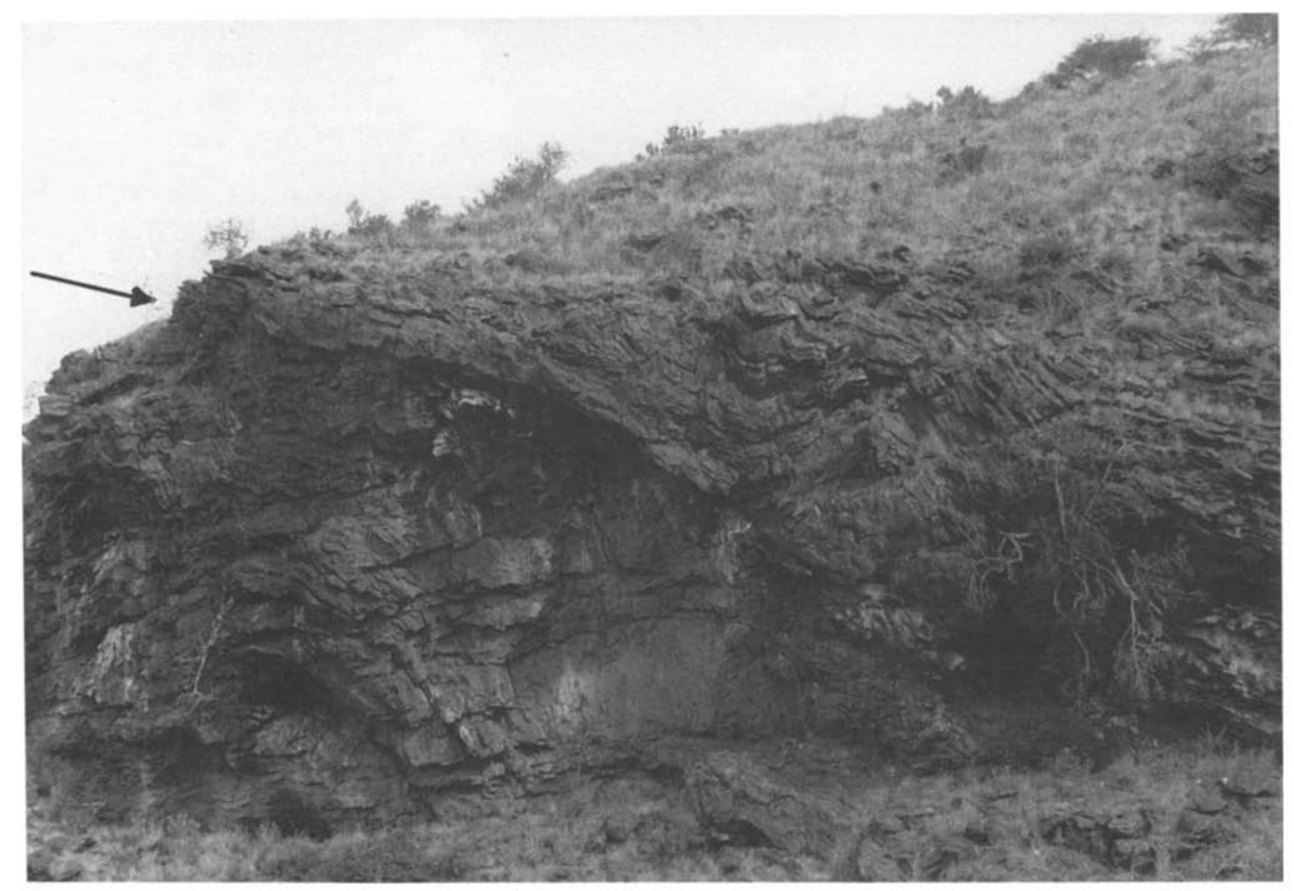

Fig. 3. $\mathrm{T}_{2}-\mathrm{T}_{4}$ thrust formed in Kuruman BIF on Glen Allen (Fig. 2). The structure cuts upwards in the stratigraphy from right to left ( $W$ to $E$ ) and the iron-formation is folded with vergency to the $E$ above and below the decoupling plane. Phyllonitization of BIF occurs up to $1 \mathrm{~m}$ thick above the thrust plane. Highest part of cliff is $15 \mathrm{~m}$ above base. For fabric see Fig. 4A.

developed parallel to the craton rim towards the end of the younger thrust episode. Late Namaqua right-lateral wrenching seems to have occurred at least along the Brakfontein-Copperton fault. Coward and Potgieter (1983) also interpreted the mylonitised Doornberg Shear Zone (Fig. 2) as an oblique slip left-lateral shear-thrust belonging to the early phase of SEdirected movements prior to back-folding. Stowe (1983) found several NW-trending mega-shear zones with left- and right-lateral movements along the Orange River in the Upington area (Fig. 1).

Potgieter (1981) showed two thrust planes in the Uitspanberg mountain (Fig. 2). Folds above these dislocations verge NE with low plunges but both thrust planes are clearly not backfolded. Just west and north of this locality Coward and Potgieter (1983) reported steeply dipping faults that duplicate the carbonate-BIF succession (Fig. 2) and interpreted these structures as back-folded thrusts.

We have found low angle, west dipping $T_{2-}$ $\mathrm{T}_{4}$ thrusts in BIF around the Glen Allen mountain farther south (Fig. 2) with phyllonites drag-folds and lineations that clearly prove thrust movement from $W$ to $E$ (Figs. 3 and 4A). From Prieska to Prieskapoort (Fig. 2) five structural zones can be recognized. In zone 1 at Prieska three fold phases are seen in BIF. $\mathrm{D}_{2}$ folds are recumbents on a metre scale, zonally developed and parallel to bedding, with axes plunging into the NW and SE quadrants along bedding planes deformed by $\mathrm{D}_{4}$ and $\mathrm{D}_{5}$ (B and C of Fig. 4). $F_{4}$ are open to isoclinal, upright to asymmetric E-vergent NNE-SSWtrending structures, and $F_{S}$ are open upright NW-trending ( $A$ and $B$ of Fig. 5). The $F_{4}$ folds may even develop into injection structures and sheared box folds, revealing plastic as well as 

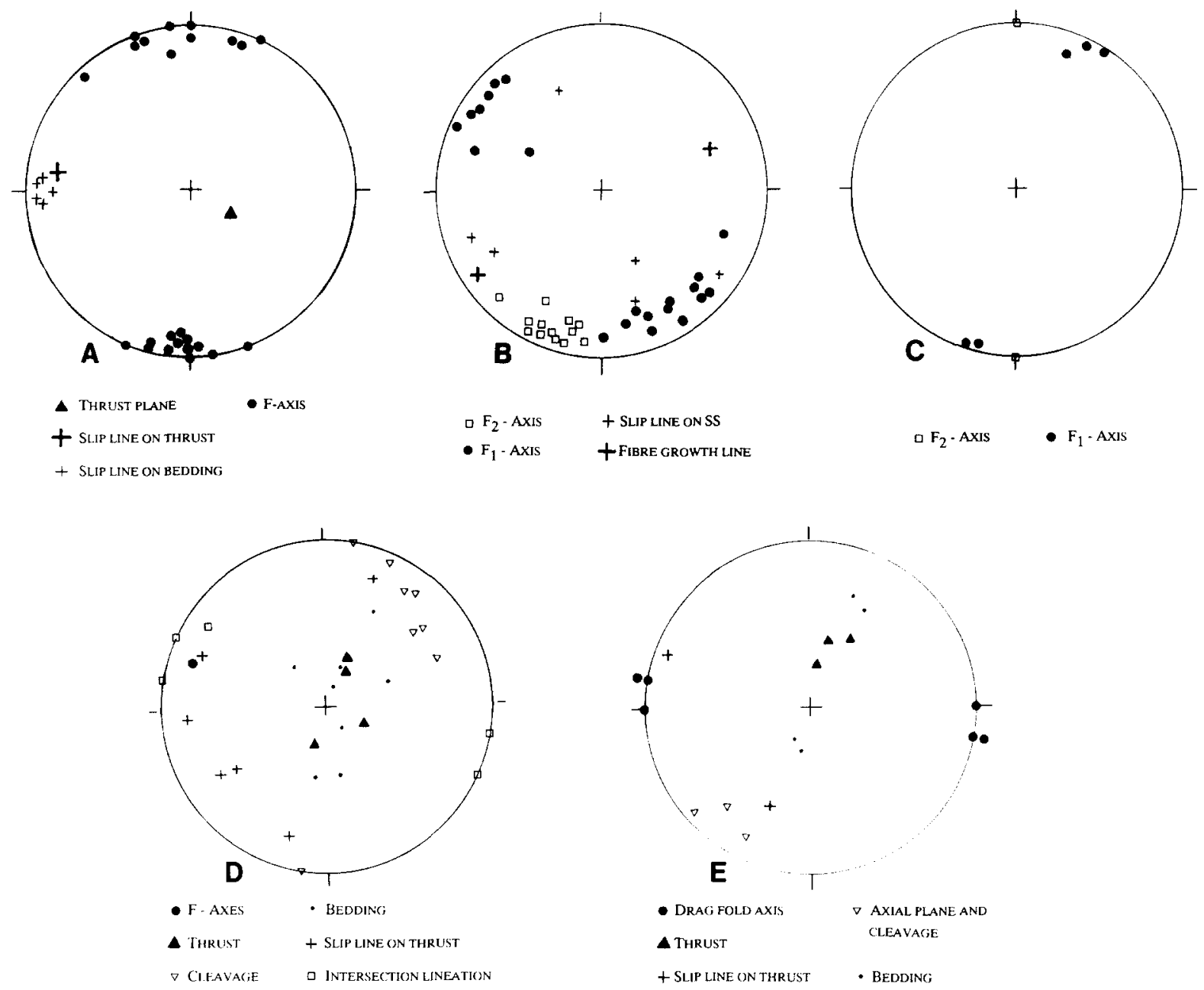

Fig. 4. Structural fabric from various localities: (A) Glen Allen on $T_{2}-T_{4}$ thrust; (B) Prieska town; (C) highway outcrops SW of Prieska town; (D) zone 2 of Fig. 2; (E) zone 3 of Fig. 2.

elastic behaviour. $D_{2}$-fold zones preferably develop in riebeckite lutite-rich thinly bedded units, whereas the thicker chert and sideritic chert layers ride on these dislocation zones. Movement above the decollements is to the east. The style and orientation of these $\mathrm{D}_{2}, \mathrm{D}_{4}$ and $D_{5}$ structures is very similar to that found in BIF of the entire study area.

In zone 2 (Fig. 2), NW-SE-trending folds and thrusts ( $C$ and $D$ of Fig. 5) verge NE and have quartz and asbestos slip fibre lineation zones up to $25 \mathrm{~cm}$ thick, trending across as well as parallel to the strike of thrusts. The axial plane foliation in riebeckite lutite bands al- ways dips westerly (Fig. 4D). In zone 3 , strike stays NW-SE but the vergency of large folds with a low plunge is clearly to the SW and riebeckite lutite foliation dips at $80^{\circ}$ to the NE (Fig. 4E). The rotated thrusts have steeper dips to the SW (Figs. 4E, 5D). This is the zone of back-folding of Coward and Potgieter (1983). Next we find a $2 \mathrm{~km}$ wide zone 4 , in which a near-vertical NW-SE-trending foliation and near-vertical lineation of shear fold closures appear as transformed structures. Then follows zone 5 with mylonites of Schmidtsdrif quartzite and Marydale granite (2.6 Ga-Potgieter, 1982). We prefer to call zone 4 the 

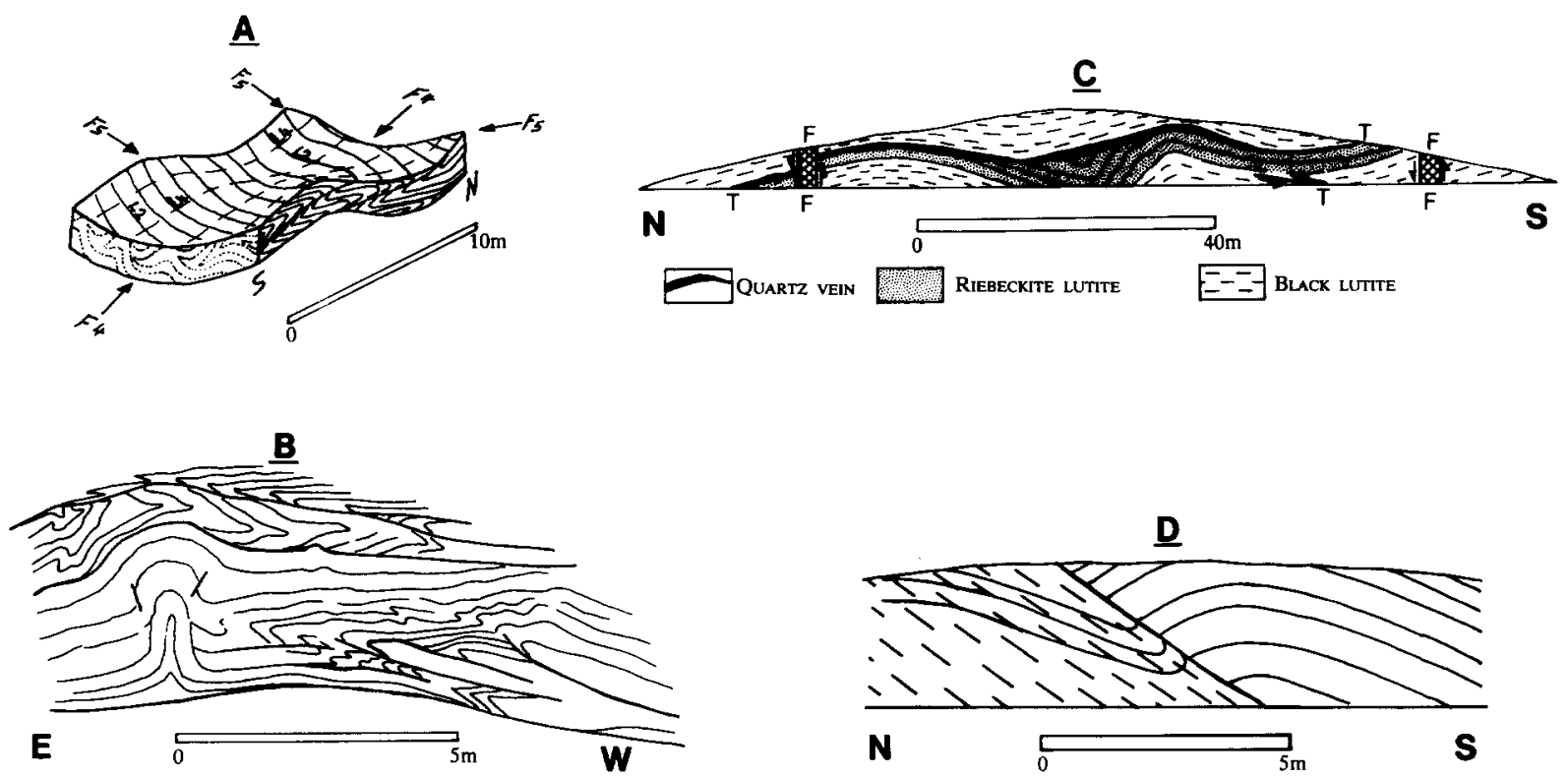

Fig. 5. Field sketches of specific structures. (A) Structural relationships at Prieska town. For fabric see Fig. 4. B. (B) Highway outcrops SW of Prieska. $F_{4}$ upright fold deforms $F_{2}$ thrusts and recumbents. For fabric see Fig. 4C. Looking south. (C) Fold and thrust behavior in zone 2 (Fig. 2) looking SW. Note folds are verging NE. For fabric see Fig. 4D. (D) "Thrust" with synthetic foliation in zone 3 (Fig. 2), rotated to SW and with slip movement nearly parallel to strike. For fabric see Fig. 4E.

Doornberg Fault Zone and zone 5 the Doornberg Mylonite. Together they form the Doornberg Lineament. Coward and Potgieter interpret zone $\mathbf{4}$ as vertically back folded thrusts and zone 5 as a left-lateral oblique shear-thrust (oblique wrench). In our opinion they both have a very similar origin. This is apparent in both cases from the relationship of shear folds to an older mylonite lineation.

S-shaped asymmetric meso shear folds in mylonitized Schmidtsdrif quartzite (Fig. 6A) bordering the Doornberg Fault Zone have a near vertical axis with a penetrative b-lineation parallel to the shear fold axes (Fig. 6B). They bear a set of older deformed penetrative mineral lineations orientated along a plane (Fig. 6B). No foliation occurs along this plane. The mylonite lineation is therefore definitely older than the b-lineation. Its plunge on the long, undisturbed limb of shear folds varies from moderate to steep in a northwesterly direction. "S" macro-folds have been mapped and " $Z$ " inferred by Potgieter (1981), the former with deformed older lineations, on the transition between quartzite-mylonite and granite-mylonite. This combination suggests sheath folds but is no proof of their existence. No closed sheaths could be followed out or seen in outcrop in the Doornberg Lineament. Some large S-shaped folds in zone 3, plunge steeply (Fig. 2). The simplest interpretation of these structural relationships together with the anticlockwise drag of $\mathrm{D}_{4}$ structures in zones 2 and 3 and with what looks like "back-folding" in zone 3 , is a first order left-lateral oblique wrench. To the west of this structure, movement was obliquely up to the $\mathrm{SE}$ at first, with closer to horizontal wrenching later on. Both phases were associated with compression across the shear zone. The first probably produced more displacement than the second. The latter was more compressive, however, with near-vertical extension along shear fold axes. This is clearly displayed by strings of horizon- 

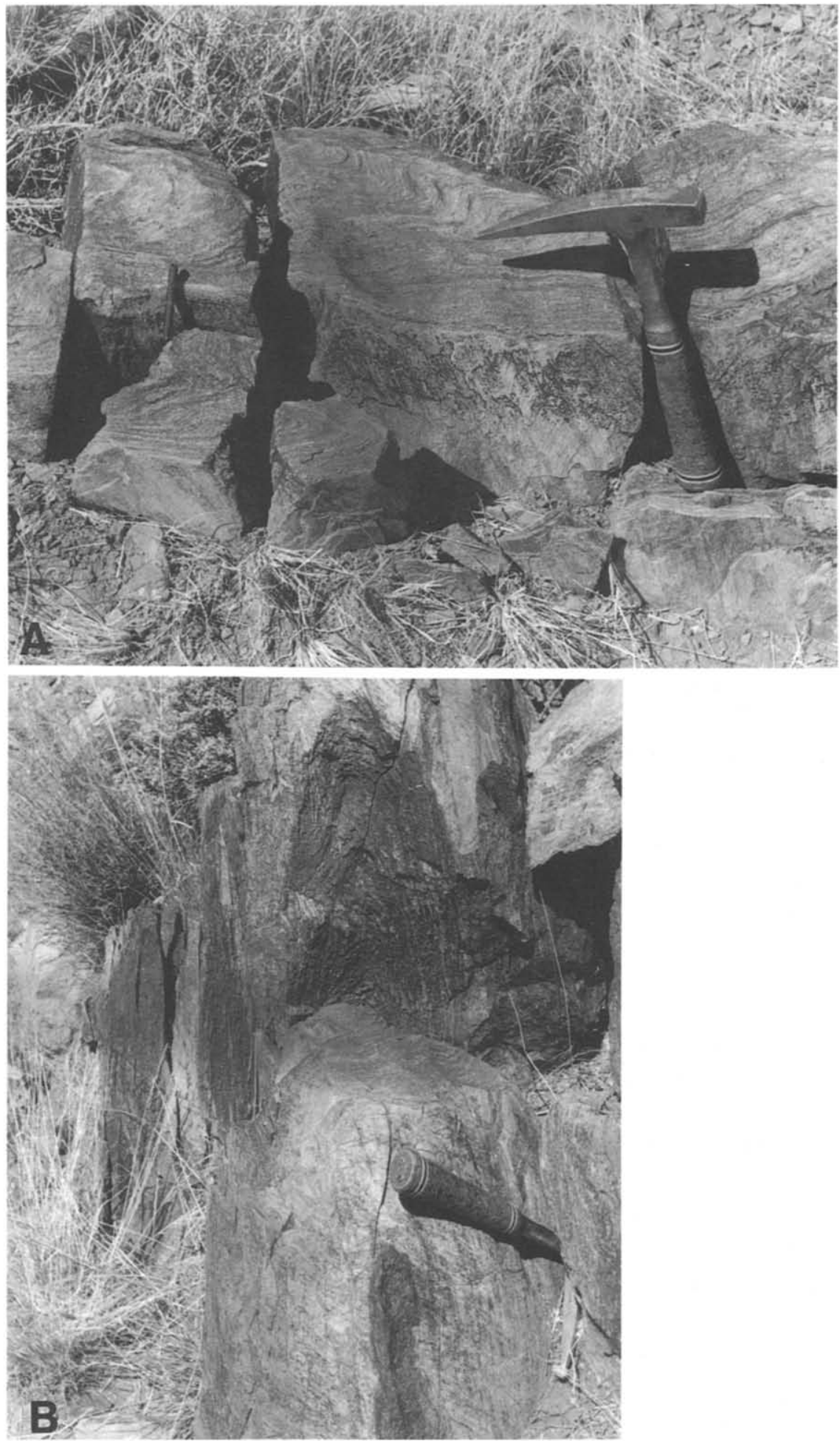

Fig. 6. Mylonitized Schmidtsdrif quartzite. (A) S-shaped shear folds looking SW with near-vertical axes (parallel to pencil). Older mylonitic lineation is parallel to hammer handle. (B) Closer look at hinge of S-shaped shear fold with blineation parallel to hinge and older deformed mylonitic lineation lying in a plane parallel to hammer handle. Looking NW. 
tally oriented tension gashes in competent chert (quartz) bands of vertically plunging shear folds in BIF of zone 4, the Doornberg Fault Zone.

Contrary to Coward and Potgieter's (1983) explanation of back-folding of earlier thrusts, which must have tilted many kilometres if not some tens of kilometres of crust between the Copperton and Doornberg Faults (Fig. 1) and which now simulates sinistral shear, we think that the bulk of the evidence is in favour of oblique left-lateral wrenching (Potgieter, 1981 ) along the Doornberg Lineament. This is responsible for the juxtaposition of Archaean granites against the Early Proterozoic Campbell Group, and most satisfactorily explains a gradual syntaxial change in strike of the early formed $\mathrm{D}_{4}$ thrusts and folds on the craton into the northwesterly direction with re-activation of some deflected thrusts that now bear strikeslip lineations in zones 2 and 3 (Fig. 2).

\section{Structures in the remaining study area}

Four different types of $D_{2}$ thrust were found in the Asbesheuwels Subgroup (Table 1) and fully described by Altermann and Hälbich (1990).

They are very common and briefly summarized here in order of increasing size. Their recorded distribution and relationship to other structural elements are shown in Fig. 7.

(1) Discrete slip planes that gradually cross from one bedding plane to the next can be followed for several metres and occur at frequencies of about one per metre thickness of strata in some sequences.

(2) Mylonitic, ferruginous carbonate and chert breccias and lenticular jaspilites and quartz veins, centimetres to decimetres thick occur subparallel to bedding, with shear phenomena clearly indicating the sense of movement which is always towards the craton. These dislocations are commonly accompanied by higher-angle synthetic splay faults. They can be followed in outcrop for up to many hundreds of metres at a time and occur at a frequency of about one per several tens of metres. These thrusts may separate units that differ in lithology.

(3) Recumbent folds are found in sheet-like zones, which can be traced between nearby outcrops. They are subparallel to bedding. Discrete shear planes have developed within these zones parallel to axial planes and at their base. The vergency and direction of folds always indicate a movement of the hanging wall towards the craton (Fig. 4B). From 0.5 to several tens of metres of strata may be deformed in this way. They may be encased above and below by an envelope of asymmetric shear folds.

(4) Bedding-parallel as well as obliquely cross-cutting zones of totally phyllonitised BIF contain subzones of chaotic folds. They may grade laterally into jaspilitic breccias or develop a very distinct "augen"-structure up to several tens of metres thick in the Orange River area.

The structures of types (3) and (4) above can be traced for kilometres and are commonly separated by 50 to $100 \mathrm{~m}$ of strata. In drill cores they appear as a profusion of small folds associated with an axial planar cleavage over considerable core lengths, whereas the mylonitic meso-augen-structure might easily be mistaken for primary "pillow and billow structures" (Beukes, 1980) that also occur in the BIF. Types (1) and (2) thrusts occur intermittently in outcrops near the base of the Asbesheuwels Subgroup between Griquatown and Kuruman (Fig. 1).

The first three types have been found as far north as Griquatown, some $130 \mathrm{~km}$ northeast and east of the craton edge (Fig. 1), with movement directed NE, E and SE.

Directly southwest of the Griquatown Fault erosion-valley NW-trending thrusts dipping SW have stacks of NE-verging folds overlying quartz and crocidolite slip fibre dislocation zones alternating with zones of tension gashes (Figs. 8A and 9A). 


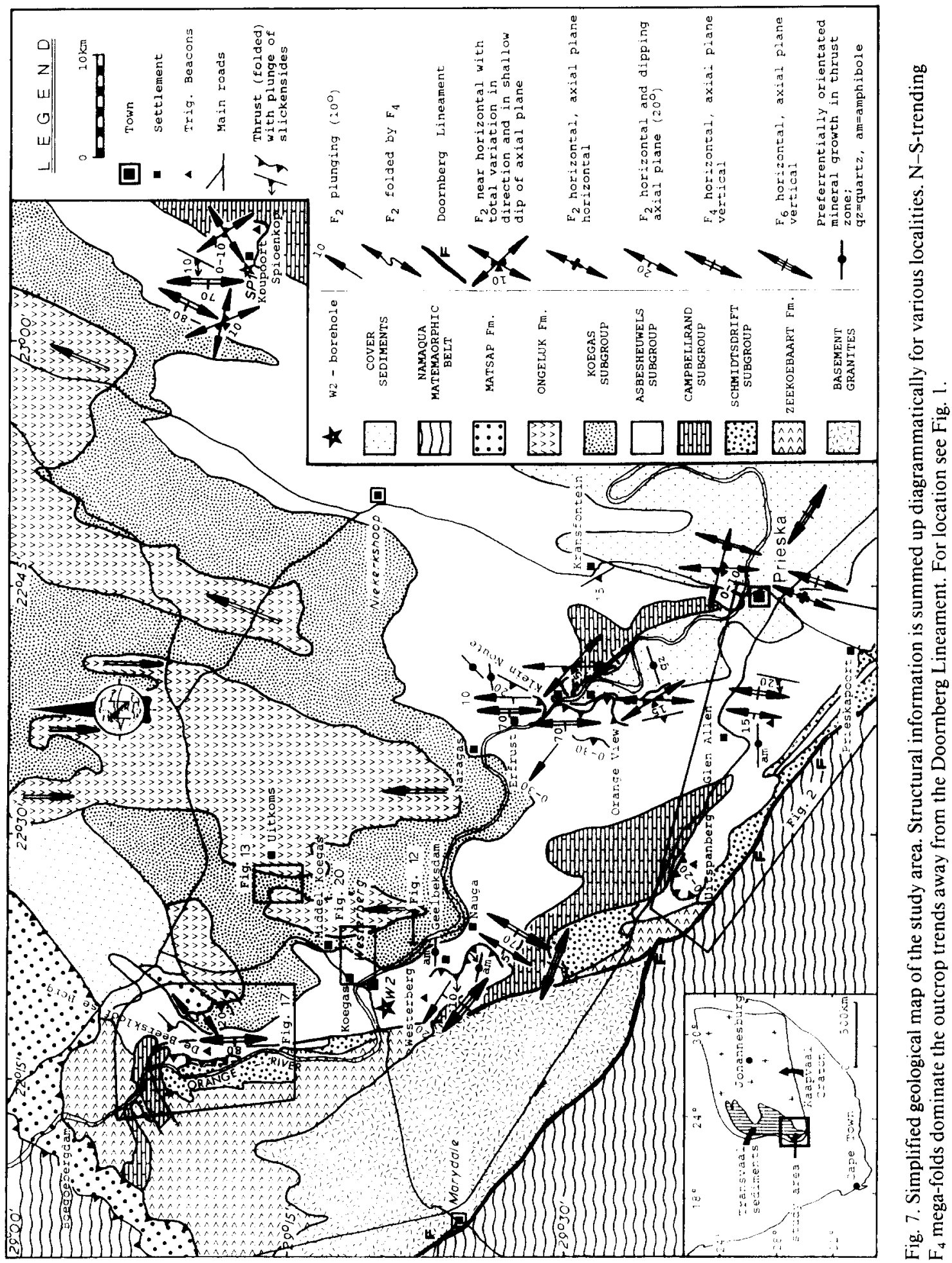




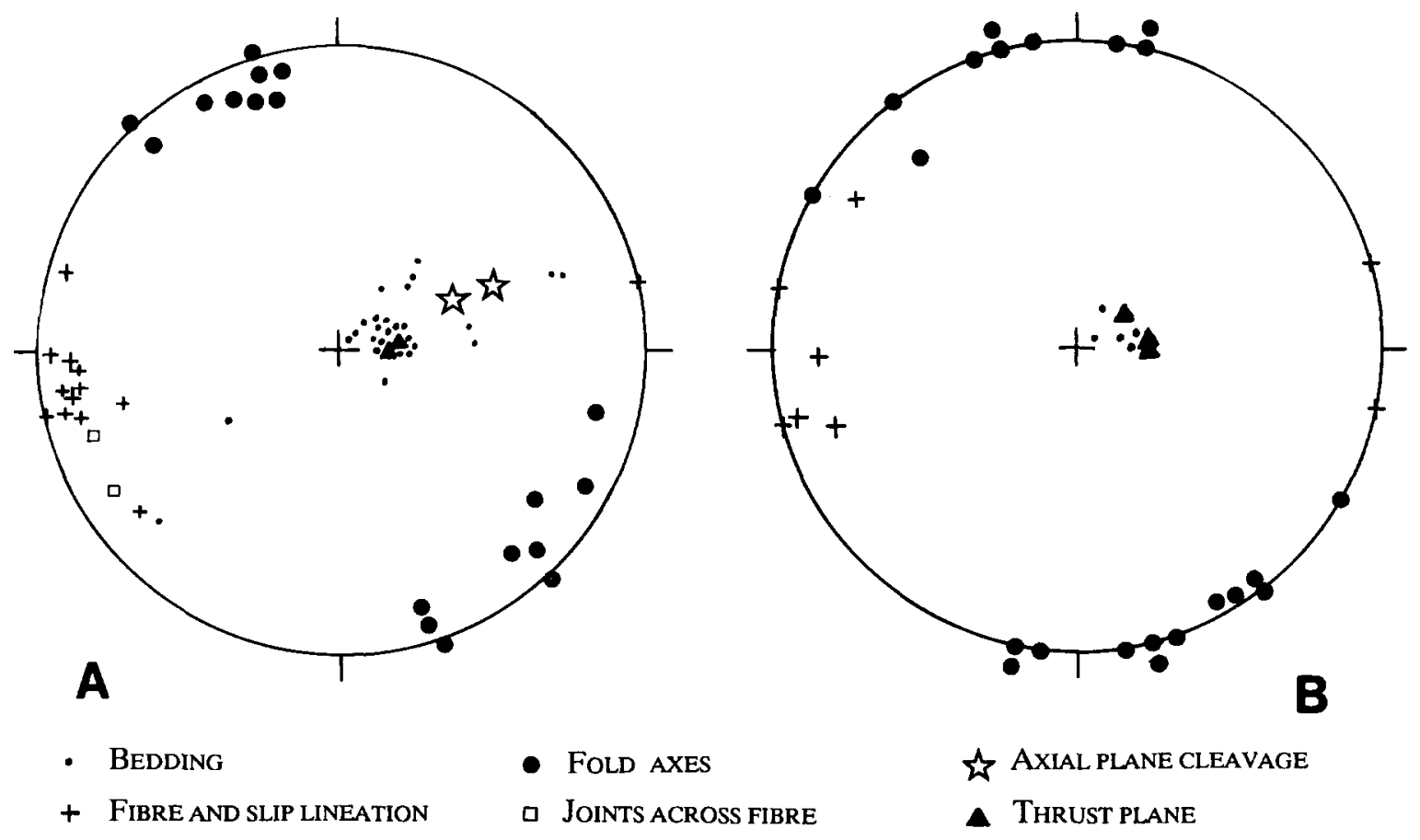

Fig. 8. Structural fabric between Koupoort and Griquatown. Refer to Fig. 1. (A) From BIF just southwest of the Griquatown Fault erosion-valley. For explanation see text. (B) From BIF 10-20 km north of Koupoort.

Farther south (Figs. 1 and 10) N-trending thrusts are lined with quartz and have overlying folded zones with internal dislocations several tens of metres thick (Figs. 8B, 9B, 9C, 9D). Thrust planes at the base of the folded stacks clearly separate lithologically differing units (Figs. 9B $(\mathrm{i})$, 9D and 10). From Spioenkop to Koupoort three thrust and thrust-fold horizons are recorded (Figs. 10 and 11 ). Several thrusts of type (3) and (4) occur between Orange View and Klein Noute in Fig. 7. Near Nauga and Geelbeksdam at the Orange River, several-centimetres long riebeckite, aegirine and acmite crystals grow with preferred orientation in thrust zones across recumbent E-vergent folds and west-dipping C-type shears. An acmite-aegirine-riebeckite-quartz-carbonate-magnetite paragenesis exists in these dynamometamorphic zones.

The oldest deformation recorded so far on the craton in Griqualand West seems to be a zone of cataclasites that parallel the steeply in- clined western limb of the Uitkoms syncline (Figs. 7 and 13-16) in the Koegas Subgroup. Movement indicators are very scarce. Some dragfolds may belong to the $F_{1}-F_{2}$ or $F_{4}$ fold phases. Microscopically, eye-structures and connecting bands are totally recrystallised by quartz and calcite, both heavily strained afterwards. The entire tectonite is a recrystallised impure marble of which parts are still seen in situ. Large amounts of fluids moved along this zone as is revealed by irregularly shaped quartzor carbonate-rich volumes of rock with nearvertical boundaries.

The overlying mixtite bears rare clasts of cataclasite but itself is neither recrystallised nor sheared or cleaved. There can be no doubt that this event of disruption and fluid penetration occurred prior to the deposition of a porous heterogeneous rock like the Makganyene mixtite immediately above. This Uitkoms cataclasite is interpreted as a splay thrust diverging from a sole in depth. This blind $D_{1}$ thrust is 

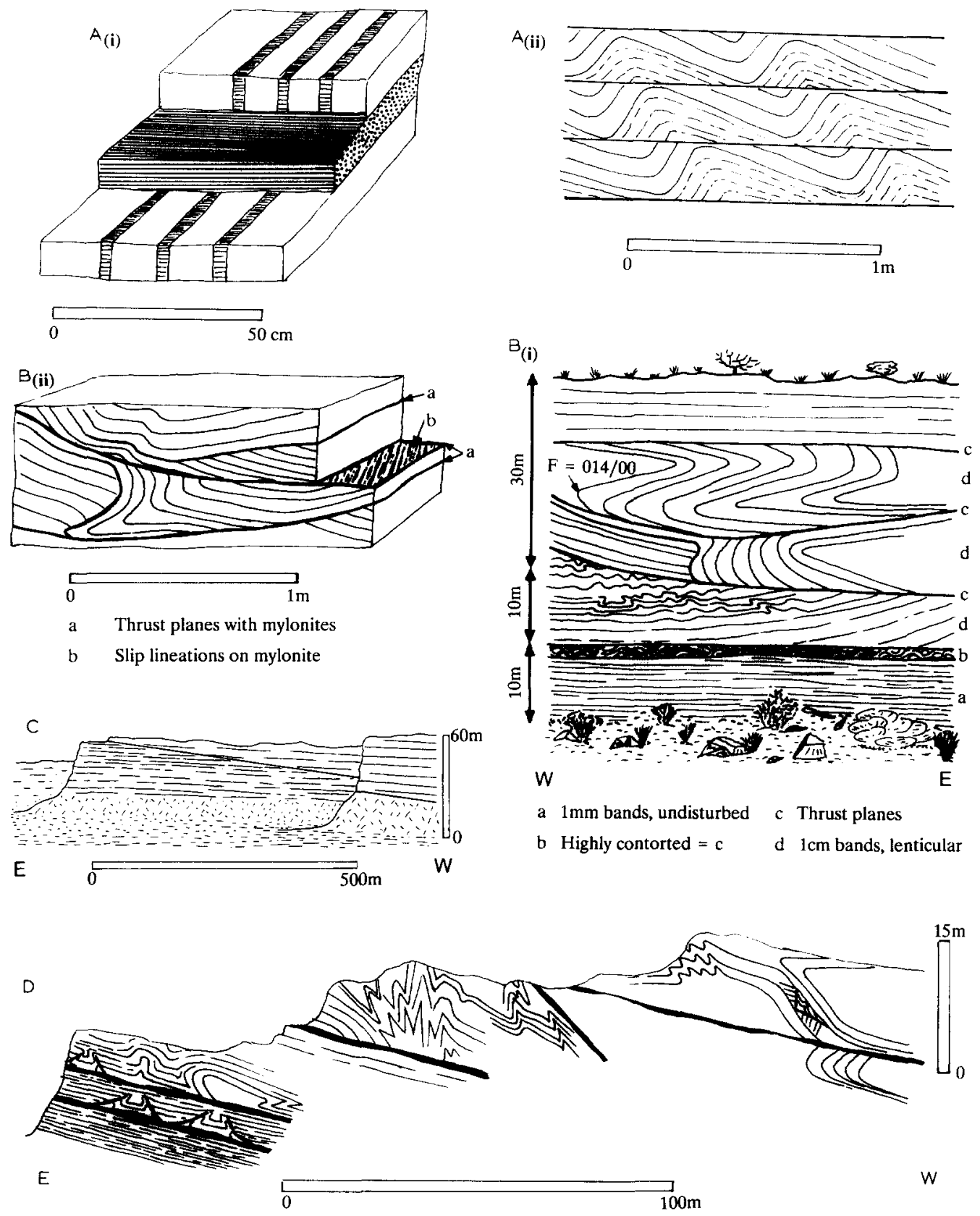

Fig. 9. Field sketches of folds and thrusts between Koupoort and Griquatown. Refer to Fig. 1. (A) Bordering the Griquatown Fault erosion-valley to the SW: (i) slip lineation zones and transverse tension gashes mark thrust zones, looking NW; (ii) stacks of thrusts and decapitated drag folds; looking SW. (B) Elandsfontein, $20 \mathrm{~km}$ north of Koupoort. Fold and thrust piles at the base of a lithologic unit in Griquatown BIF. For fabric see Fig. 8B. (C) Doornlaagte and Spioenkop $5-10 \mathrm{~km}$ east and north of Koupoort. Fold and thrust relationship to lithology and bedding in lower Griquatown BIF. For location see Fig. 10. For fabric see Fig. 8B. 


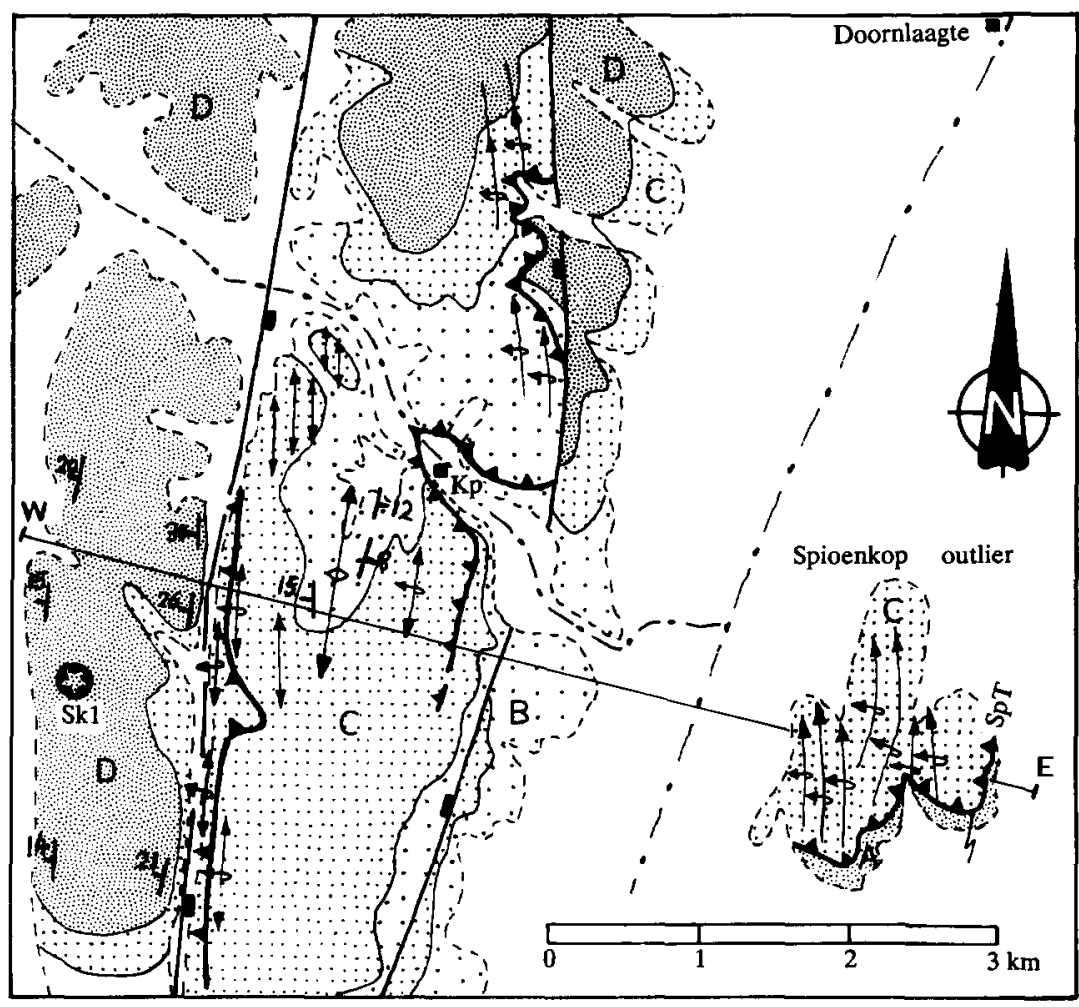

Fig. 10. Geological map of Doornlaagte-Koupoort area. After du Plooy (1986), amended, and the authors' own work. Various mappable units of mainly allochemical banded iron-formation overly each other from bottom to top in the order A, B, C, D. The general dip is between 5 and 10 degrees to the west and has been omitted, except where it deviates significantly from these limits. One larger anticline and numerous fold zones with asymmetric to recumbent east-verging folds are indicated schematically. Thrusts shown were mapped. Koupoort $(K p T)$ thrust, and Spioenkop $(S p T)$ thrust are cutting upwards through the lithology to the east. Most bedding plane thrusts as inferred from fold zones and correlation with data from borehole Sp 1, are not shown on the map. See also Fig. 11 for an interpretation of the structure. $K p=$ Koupoort farm house.

between 2500 and $2240 \mathrm{Ma}$ in age, and possibly initiated $\mathrm{N}$-S-trending $\mathrm{F}_{1}$-folds in its hanging wall from Kuruman to Prieska (Fig. 1). The eastward convex shape of these $F_{1}$ axial traces around the Maremane double-plunging anticline is seen as part of this development. Re-activation of these structures may have occurred during $\mathrm{D}_{4} \mathrm{~N}-\mathrm{S}$ folding. This is also suggested by the two unconformities separating the Koegas, Makganyene and Ongeluk units (Fig. 12). The Ongeluk seems to have undergone posthumous folding along older trends. Aggressive fluids have moved along only one other dislocation plane in the study area. It is a $T_{2}$ thrust separating carbonates verging $W$ and facing $E$ from Schmidtsdrif shales facing and verging east in leg $\mathrm{AB}$, of the profile in Fig. 18. This is the ideal stratigraphic horizon for a sole thrust to develop relative to all younger units. Thus the Uitkoms cataclasite with its evidence for fluid involvement may be closely linked to a sole thrust.

The fabric of bedding and lineations (Fig. 19) from the Koegas-Westerberg area (Fig. 7) reveals that $\mathrm{N}$-S-trending folds plunging at low angles dominate. These are mainly $F_{4}$ folds, many of which are E-vergent (Figs. 19A and 19C). But some interference of $F_{4}$ with $F_{2}$ recumbents and $F_{6}$ (Table 2 ) occurs producing fold plunges at larger angles and in many directions (Figs. 19B and 19D).

In this same area, $200 \mathrm{~m}$ thick decollement 


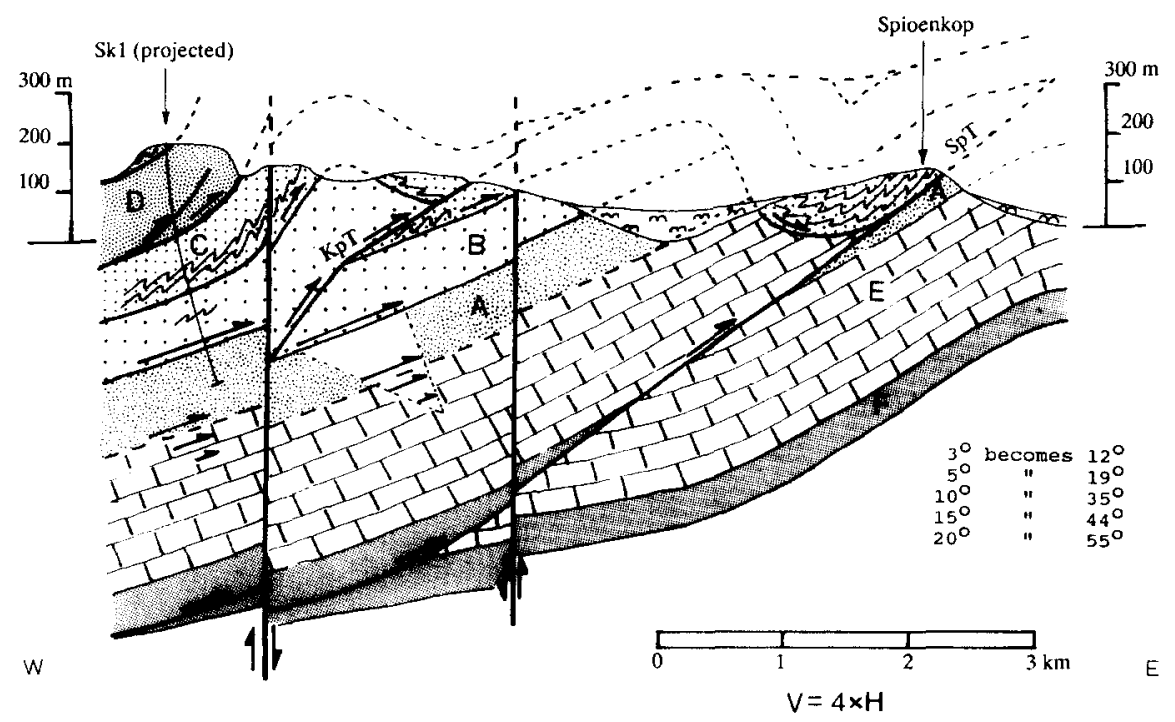

Fig. 11. Interpreted cross-section through the map, Fig. 10. Lithology as for Fig. 10. Unit A was apparently intersected at the bottom of hole Sp 1. This and the interpretation that A (and not any other horizon) overlies carbonates at the eastern slopes of Spioenkop, determines the reconstruction of the lower half of the figure. Thicknesses of units. Campbell Rand carbonates (E) and Schmidtsdrif shales + quartzite (F) are estimates. The interpretation is based on the surface and the drill-hole data, assuming that the lithological correlation across the valley to Spioenkop is correct. This correlation is neatly corroborated by the presence of a well-developed fold zone that consistently occurs near the base of unit $\mathrm{C}$. The reconstruction assumes considerable differential bedding thrust slip (shown schematically by the slip-vector triangle) as is evident on meso- to macro-scales from Fig. 9B, (i) and (ii). This affects an earlier thrust cutting down the lithology to the east, and placing unit $\mathrm{C}$ on $\mathrm{A}$ at Spioenkop. A logical deflection of $\mathrm{Sp} 1$ is assumed because in doing so it brings intersected horizons into very good alignment with surface data and because of observed dip angles relative to core. Note that the details shown here, differ from those that can be shown in Fig. 24.

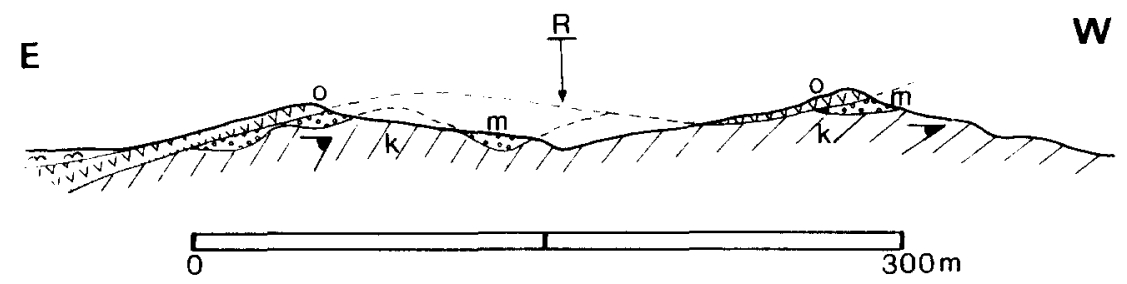

Fig. 12. Sketch profile through the western flank of the Libertas syncline. For location see Fig. 7. Two erosional episodes are in evidence. The earliest pre-Makganyene erosion occurred during or after considerable tilting of Koegas beds to form a high-angle unconformity. The later, pre-Ongeluk erosion produced a low-angle unconformity with the Makganyene. Note that dips in the Koegas Subgroup become steeper to the east as the axial plane of the syncline is approached. $K=K o e g a s$ Subgroup, $M=$ Makganyene mixtite, $O=$ Ongeluk lava, $R=$ river.

zones with recumbent $D_{2}$ fold stacks exist in BIF (Altermann and Hälbich, 1990).

The largest folds that developed during $\mathrm{D}_{2}$ are the originally north-plunging, now reclined north-plunging mega-anticlines with Schmitsdrif and Campbell Rand cores found on Bo
Seekoebaard (Fig. 17). The intervening synclines were thrust-out during $\mathrm{D}_{2}$ and the structures were co-axially refolded by $\mathrm{F}_{4}$ producing type (3) (Ramsay, 1967) interference patterns. $F_{2}$ and $F_{4}$ both plunge north to day in this area. 


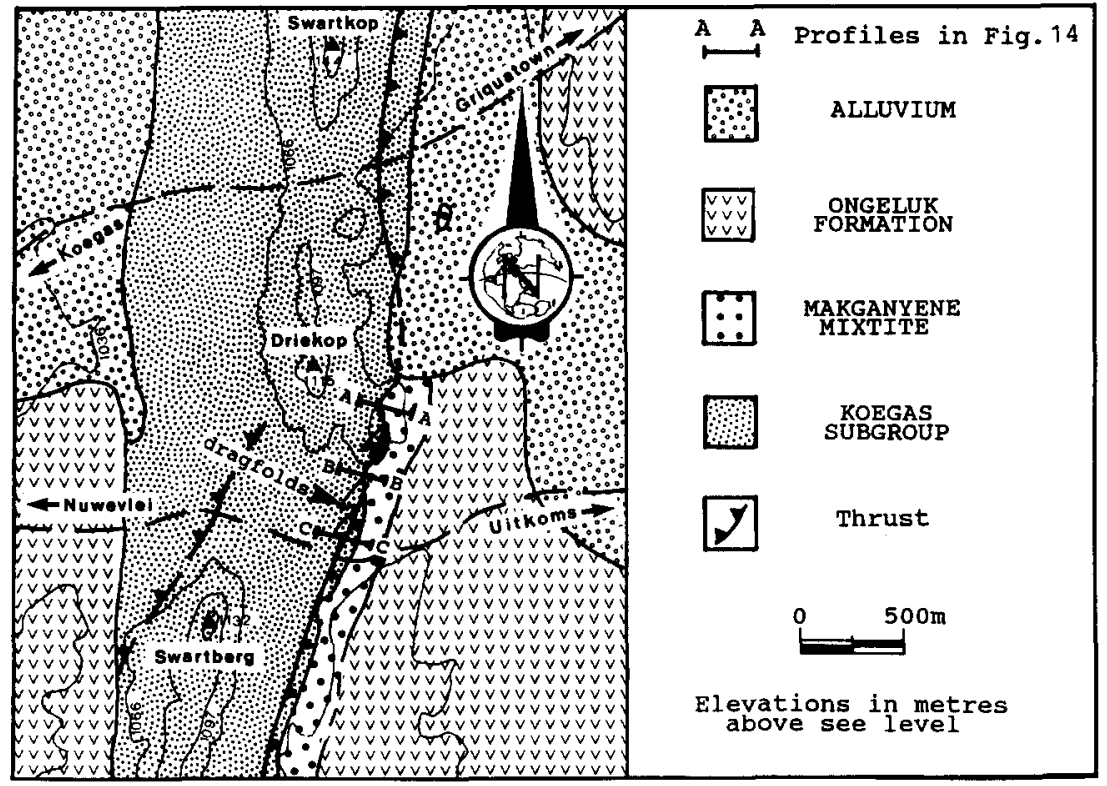

Fig. 13. Map of the Nuwevlei-Uitkoms area. For location see Fig. 7.

$\mathbf{W}$

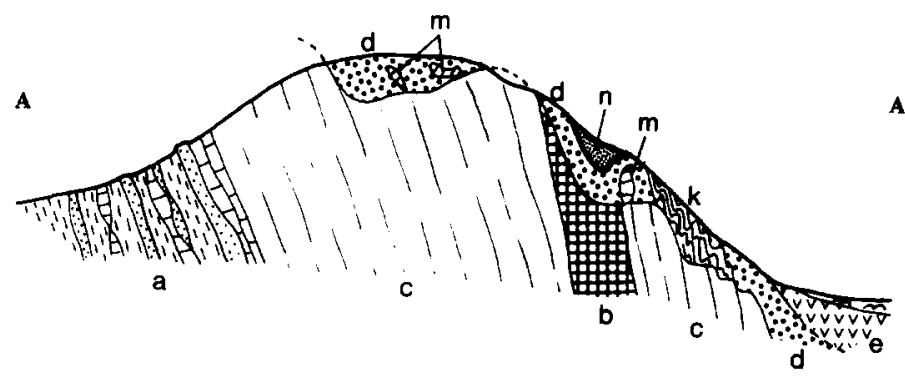

$\mathbf{E}$
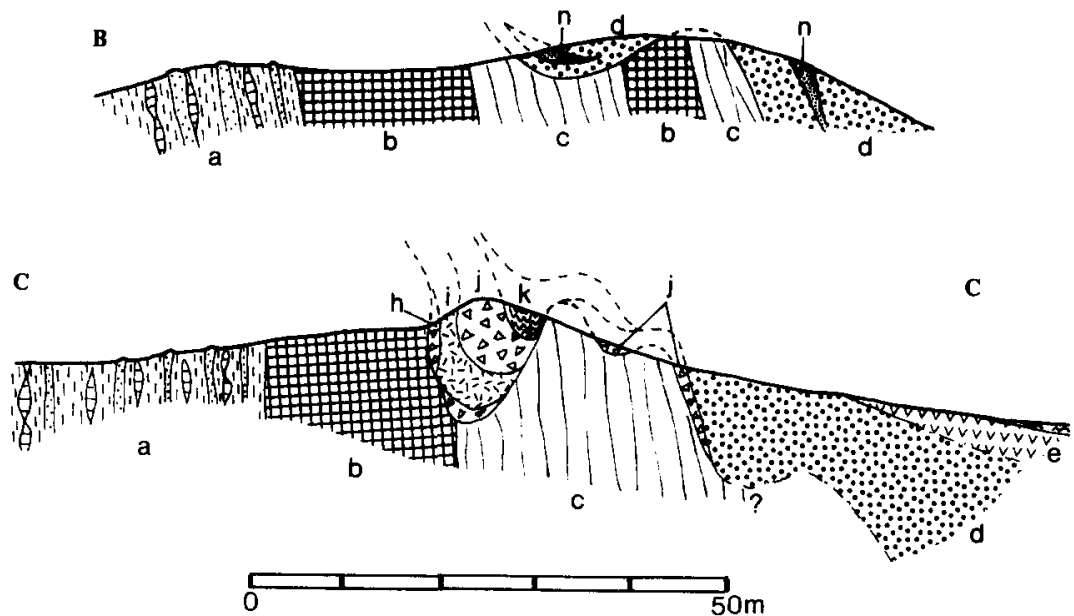

Fig. 14. Three short sections across the western limb of the asymmetric $F_{4}$ Uitkoms syncline. For location see Fig. 13 . The bedding-parallel cataclasite in Koegas beds predates later $F_{4}$ folding and the angular unconformity on which the Makganyene mixtite was deposited. $a=$ Koegas Subgroup; $b=$ totally recrystallised carbonate and/or siliceous cataclasite partly with an augen structure in the Koegas Subgroup; $c=$ Koegas Subgroup limestone with chert lenses (parent rock of b); $\mathrm{d}=$ Makganyene mixtite; $\mathrm{e}=$ Ongeluk lava; $\mathrm{h}-\mathrm{j}=$ basal conglomerate of Makganyene; $\mathrm{i}$ has a black carbonaceous matrix containing angular fragments of cataclasite; $k=$ contorted laminae of magnetic chert and limestone (varvite?); $\mathrm{m}=$ carbonate clasts floating in mixtite; $\mathrm{n}=$ lenses of sandstone floating in mixtite. 


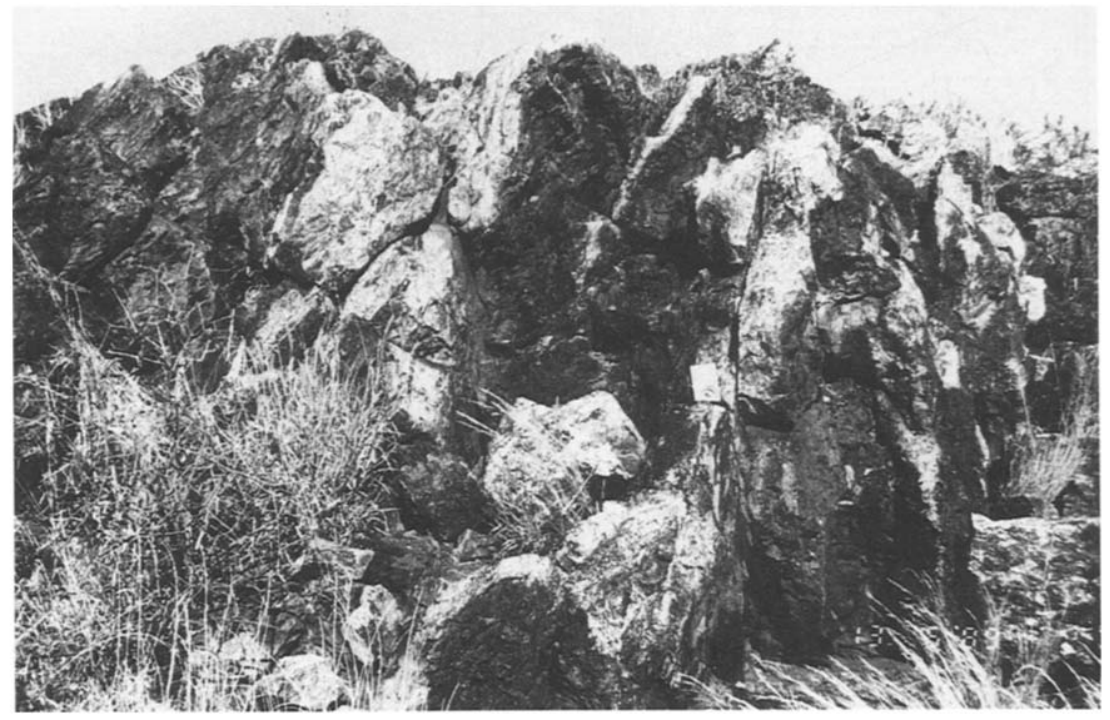

Fig. 15. Outcrop of the Uitkoms cataclasite zone on Uitkoms. Dark = carbonate recrystallisation. White $=$ siliceous recrystallisation. Note irregular, lenticular form and near vertical attitude. Looking south. Difference in elevation is $15 \mathrm{~m}$.

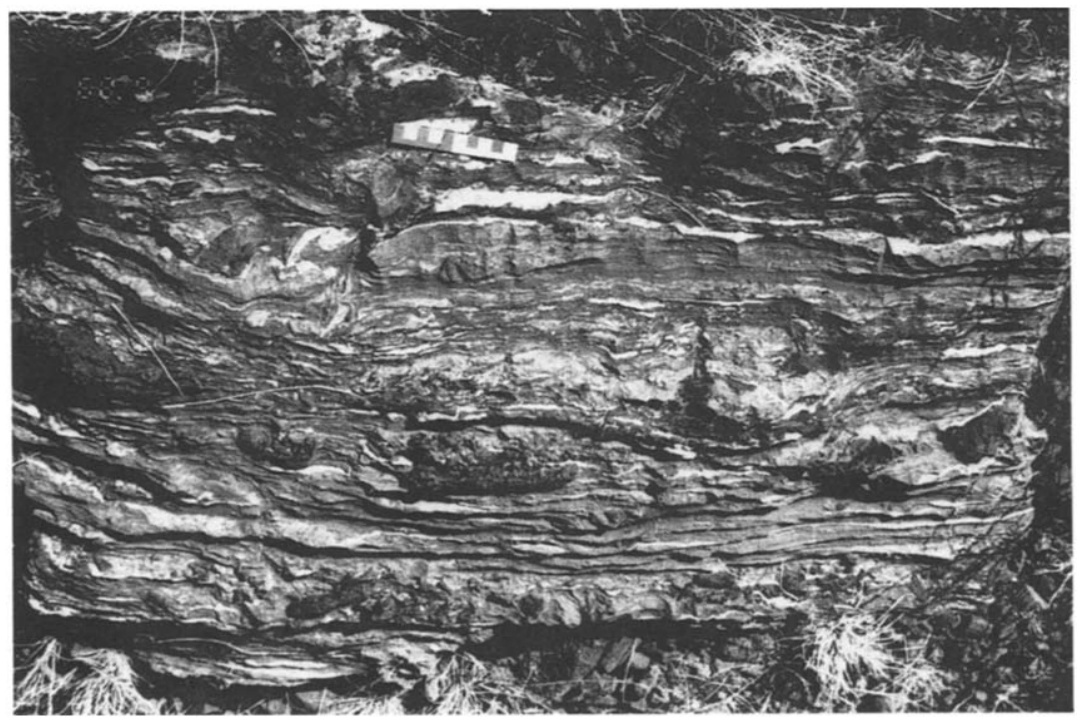

Fig. 16. Uitkoms cataclasite-detail showing lenticular structure. Scale is in centimetres.

Stacking of $\mathrm{F}_{2}$-folds and thrusts, tectonic duplication of Koegas and BIF strata as well as refolding of $\mathrm{F}_{2}$ by $\mathrm{F}_{4}$ is also seen in other areas (Figs. 20 and 21 ).

$T_{4}$ thrusts displacing $T_{2}$ and $T_{3}$ are shown in Fig. 17. The relationship of $T_{3}$ to $T_{2}$ structures is also clear from Figs. 17 and 22. Matsap beds
(Table 1) tectonically overlie Koegas, Makganyene and Ongeluk strata that were thrust and sheared previously. The Matsap klippe has a basal $T_{3}$ thrust breccia consisting of very small angular fragments of Koegas and BIF derivation in a ferruginous matrix.

$T_{3}$ thrusts and S- to SE-verging horizontal $F_{3}$ 
folds have developed in the Matsap beds as described by Vajner (1974b) for the area around Boegoeberg Dam (Fig. 7). These structures very rapidly die out or are absent in older strata southwards and it seems that the Volop Group is tectonically decoupled from the older strata by a $T_{3}$ sole thrust south of Boegoeberg Dam. Several klippes are outcropping to the south (Figs. 1 and 7), one of which underlies Groot Witberg (Fig. 17). The $F_{2}$ folds in Asbesheuwels Subgroup on Bo Seekoebaard (Fig. 17) have north-plunging axes and form type (3) interference (Ramsay, 1967) with $F_{4}$ as outlined above. One would expect type (2) interference patterns if they were refolded $\mathrm{F}_{3}$ structures.

In the area between Seekoebaard 1 and Boegoeberg Dam west of the Orange River (Figs. 7 and 17), Zeekoebaart, Schmidtsdrif and Matsap strata all display two cleavages in finegrained rocks. The younger, non-penetrative and spaced $S_{6}$ cleavage trends E-W and is approximately vertical everywhere. On Seekoebaard 1 and 2 it crenulates an older $S_{2}$ that is axial planar to remnants of large reclined NEtrending $\mathrm{F}_{2}$ folds in Schmidtsdrif meta-quartzites. They plunge to the NW or $\mathrm{N}$ and are transected by thick bedding-parallel quartzite mylonites (Figs. 23A and 23B). Farther north, grey Matsap conglomerates and quartzites tectonically overlie the Zeekoebaart meta-lava with a different style of $D_{3}$ folds, thrusts and cleavages (Fig. 23C).

$\mathrm{F}_{4} \mathrm{~N}$-S-trending folds refolded the Matsap and all older cover rocks. The intensity of these folds of which the Orange River syncline (Fig. 1) and the synclines in the Ongeluk Formation (Figs. 1 and 7) are examples, decreases from $\mathrm{W}$ to $\mathrm{E}$. Those in Ongeluk and older rocks seem to be posthumous folds following older $F_{1}$ synclines.

The Westerberg dextral oblique-slip fault (WF-Fig. 17), described by Vajner (1974b) as the Doringberg Fault, is probably the youngest tectonic feature in the area under investigation. Altermann and Hälbich (1990) discuss the possibility that this feature which is a splay-fault off the Doornberg Lineament (Fig. 1), has rejuvenated previously refolded older thrust planes. This happens in the south of Fig. 17. Farther north on this figure, older $D_{2}$-recumbents and $T_{2}$-thrusts are refolded by N-S-trending $F_{4}$ and the Westerberg Fault merges with $T_{2}$ and $T_{4}$ structures.

The Schmidtsdrif and Naute shales and phyllites each have only one $\mathrm{N}$-S-trending steeply west dipping axial plane $S_{2}$ cleavage (Fig. 17). This structure cannot be genetically linked to the Westerberg Fault because in both cases the cleavage is developed with equal intensity and attitude next to and several kilometres away from it.

The age of the Uitkoms cataclasites $\left(D_{1}\right)$ relative to the oldest deformations $\left(D_{2}\right)$ seen in the BIF of the Orange River of Fig. 17 is not certain. $D_{2}$ and $D_{1}$ may be of very similar age, but the intensely recrystallised nature of the Uitkoms zone in thin section, and without a prominent lineation suggests that it may have a different origin, possibly as a splay thrust rising from a sole in Schmidtsdrif shales.

\section{Discussion}

\section{Age of deformations}

The absolute age of deformation events described above can only be roughly comprehended from dated volcanic rocks which often have overlapping error margins of hundreds of $\mathrm{Ma}$, probably in part because they were dynamically metamorphosed at least once. Seven events are recorded (Table 2)

$D_{1}$

It is now certain that the deformations on the craton predate the deposition of the Makganyene diamictite and the extrusion of the On- 
Geological Map of the Bo Seekoebaard, Lelikstad, Pypwater area

Sources: Own mapping, photo interpretation and re-interpretation of the map of Vajner (1974)

\section{LEGEND}

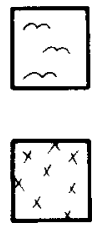

ALLUVIUM

WESTERBERG DYKE

basic intrusion

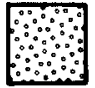

MATSAP FORMATION

conglomerates, grits and sandstones

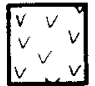

ONGELUK FORMATION

basic lava

\section{UNCONFORMITY}

$\because \because \because$ Makganyene diamictite

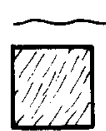

KOEGAS SUBGROUP

siltstones, shales and limestones

ASBESHEUWELS SUBGROUP

orthochemical and allochemical BIF

NAUTE FORMATION

$$
\text { shale with chert bands }
$$

CAMPBELLRAND SUBGROUP

carbonates and rare tuffs

mainly shales and phyllites

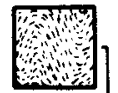
with chert bands

SCHMIDTSDRIF SUBGROUP

mainly quartzites

UNCONFORMITY

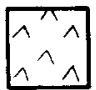

ZEEKOEBAART FORMATION

basic lava
SBA seekoebaard Antiform

HBS Hardeberg synform

WI F witberg Fault

$W F$ westerberg fault

$\odot / \square / \Delta$ survey spot; farm house; trig. beacon

Farm boundaries

$2,-\begin{aligned} & \text { Geological boundary known - } \\ & \text { extrapolated }\end{aligned}$

Form lines - photo interpretation

Axial planes: Number referes to

* $\sqrt{2} \rightarrow$ open arrows: $\begin{aligned} & \text { relative age. } \\ & \text { and dip of axial plane. }\end{aligned}$ closed arrows: Specific plunge.

$T / \mp / \uparrow$ strike and dip of beds, sense unknown: $67 / 59 / 56$ known; overturned

Th0 Thrust and thrust-fold plane (T) fault $(F)$ - observed, dip direction indicated $-F-T=$ Thrust and thrust-fold plane (T), interpreted or inferred 


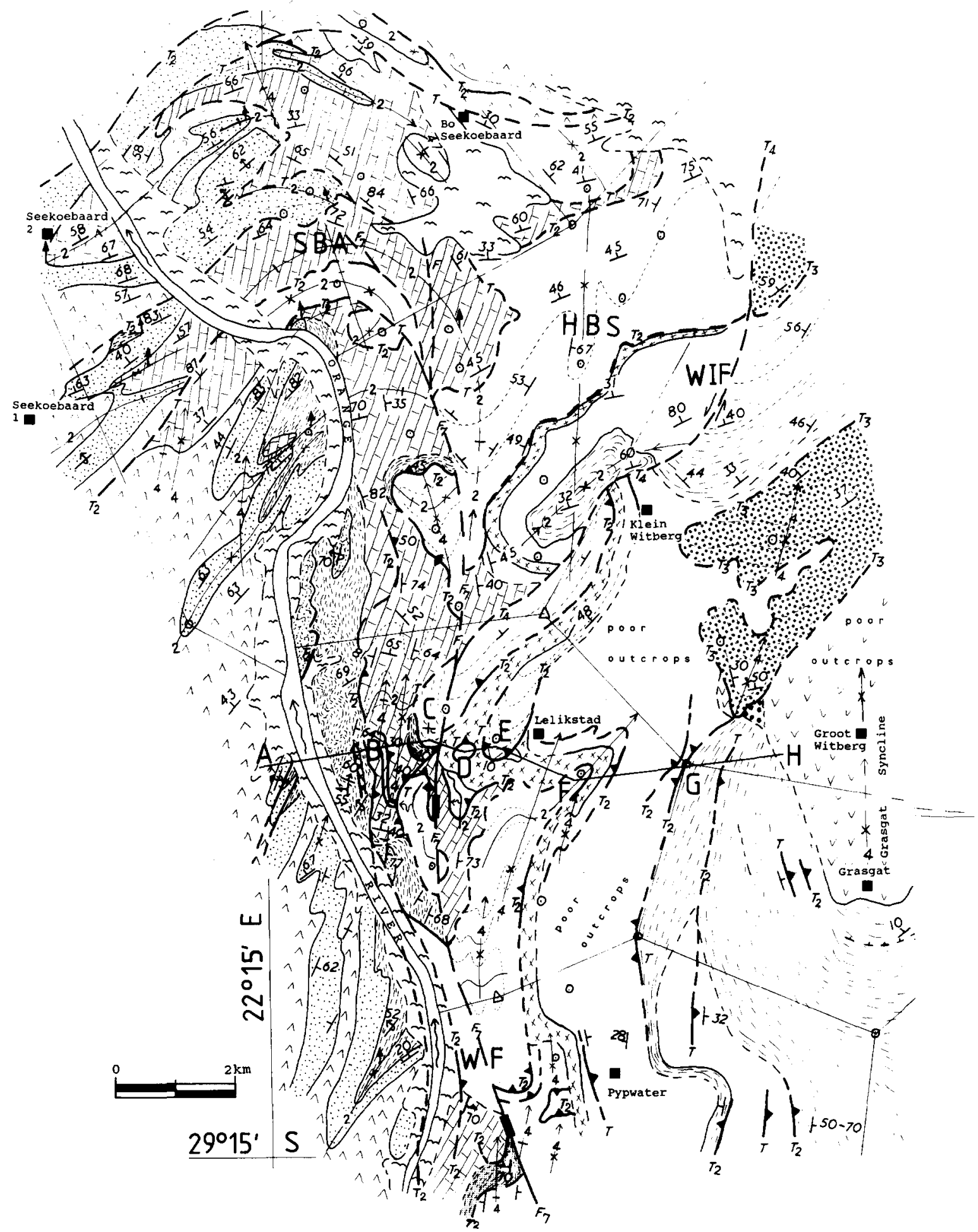

Fig. 17. Geological map of the Bo Seekoebaard-Lelikstad-Pypwater area after Vajner (1974) as amended, and the authors' own mapping. For location see Fig. 7. For description see text. 


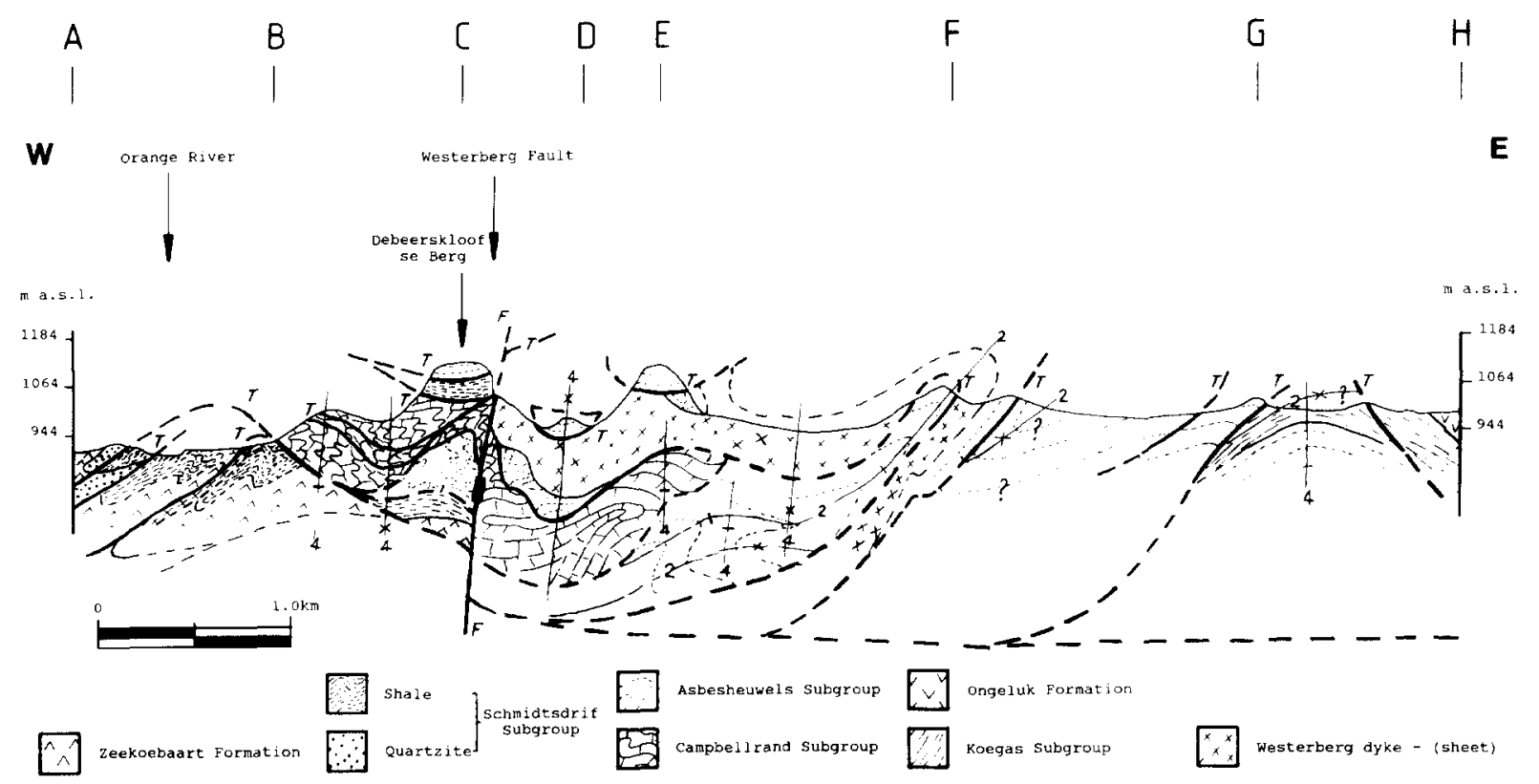

Fig. 18. Sections A-H from Fig. 17. Note the style of deformation of $F_{2}$ (recumbent north-plunging folds) and thrusts refolded by upright to $E$-vergent $F_{4}$. Late Westerberg faulting transects all older structures.

geluk Andesite Formation with an age of $2240 \pm 57 \mathrm{Ma}$ (Walraven et al., 1982) or $2239_{-92}^{+90}$ Ma (Armstrong, 1987), but postdate the deposition of the Koegas Subgroup (2400$2300 \mathrm{Ma}$ ?) The $\mathrm{D}_{1}$ - episode is therefore older than the Kheis-Koranna orogeny $(2.2-2.0 \mathrm{Ga}$; Barton et al., 1986), and thus the first orogenic event of post-Archaean but pre-Ongeluk age so far known in the region under investigation.

$D_{2}$

The slump folds, decollements, mega recumbents, recumbent fold stacks and thrusts that are considered to belong to this episode, seem to represent an extended period of movements that started just after sedimentation of the Kuruman BIF, and in the present study area finally affected the entire Ghaap Group (Table 1). $D_{2}$ structures have not been observed in Makganyene or Ongeluk strata. However, a set of shear planes displacing $\mathrm{D}_{2}$ thrust breccias also affects the Makganyene Formation (Fig. 22), but not the Matsan Group. The cor- relation of $D_{2}$ with $D_{1}$ is possible but uncertain and it is preferable to keep them separated (Tables 1 and 2). It is also possible that some of the earliest slump folds classed as $D_{2}$ here are earlier than $D_{1}$ and that some of the latest $\mathrm{D}_{2}$ cataclasites in BIF only just pre-date the deposition of the Makganyene diamictite.

$\mathrm{D}_{2}$ movements are therefore younger than the age of deposition of the Kuruman BIF (2432 $\pm 31 \mathrm{Ma}$, Trendall et al., 1990), but apparently older than the Ongeluk lava (2239 $\mathrm{Ma})$. They also pre-date the intrusion of the metamorphosed Westerberg dyke-sheet (Fig. 17). Certainly $D_{1}$, but parts of $D_{2}$ as well, are older than the earliest deformations (Stowe, $1986 ; \mathrm{KF}_{1}$ ) recorded from the Kheis Subprovince (Table 2 and Fig. 1 ), thought to have happened about $1750 \mathrm{Ma}$ ago. The movement directions and vergencies of $\mathrm{KF}_{1}, \mathrm{KF}_{2}, \mathrm{D}_{1}$ and $\mathrm{D}_{2}$, however, are comparable. We conclude that already in Early Proterozoic times several easterly (cratonward) directed pulses deformed pre- and post- Makganyene strata. A 

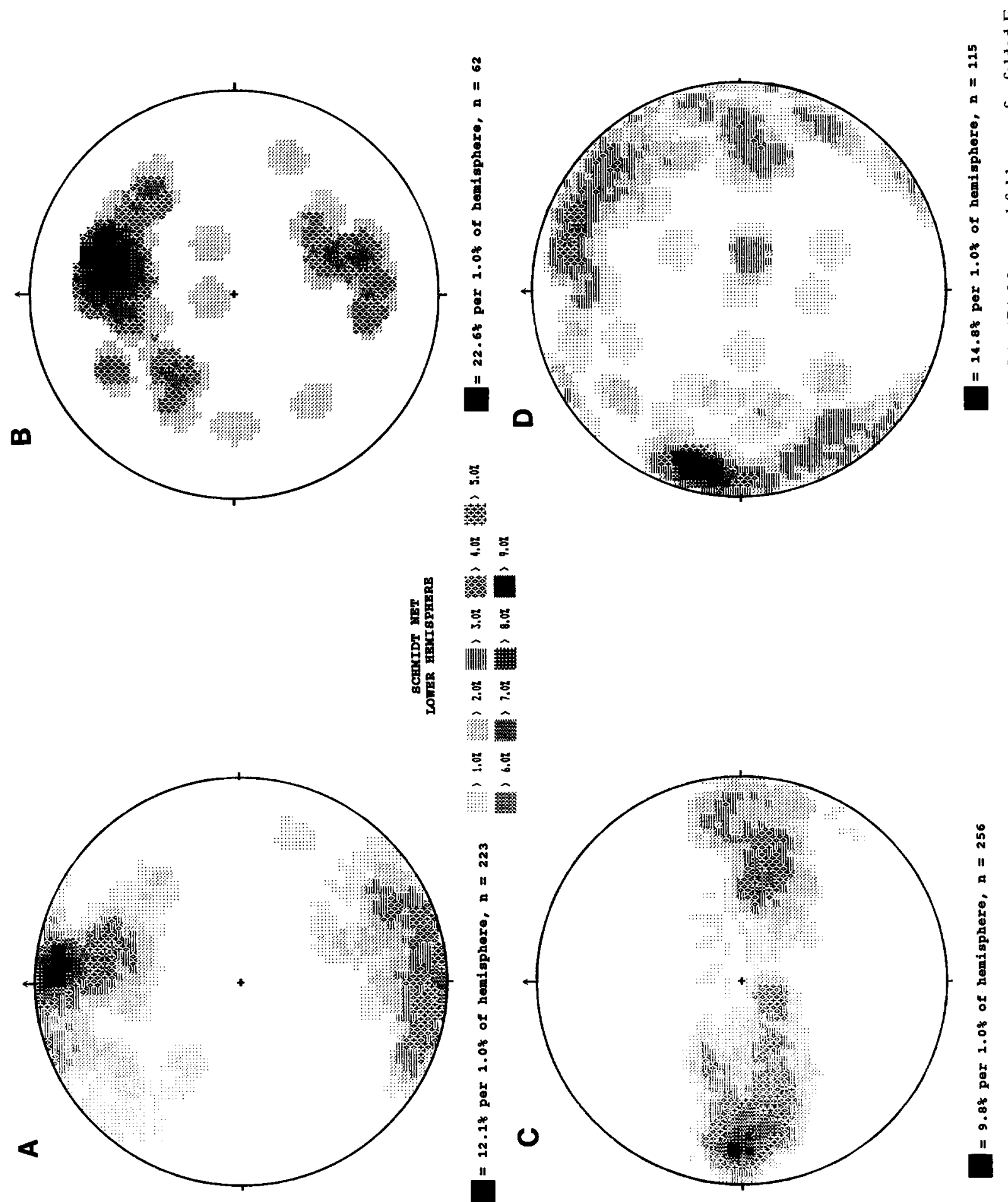

5

繁
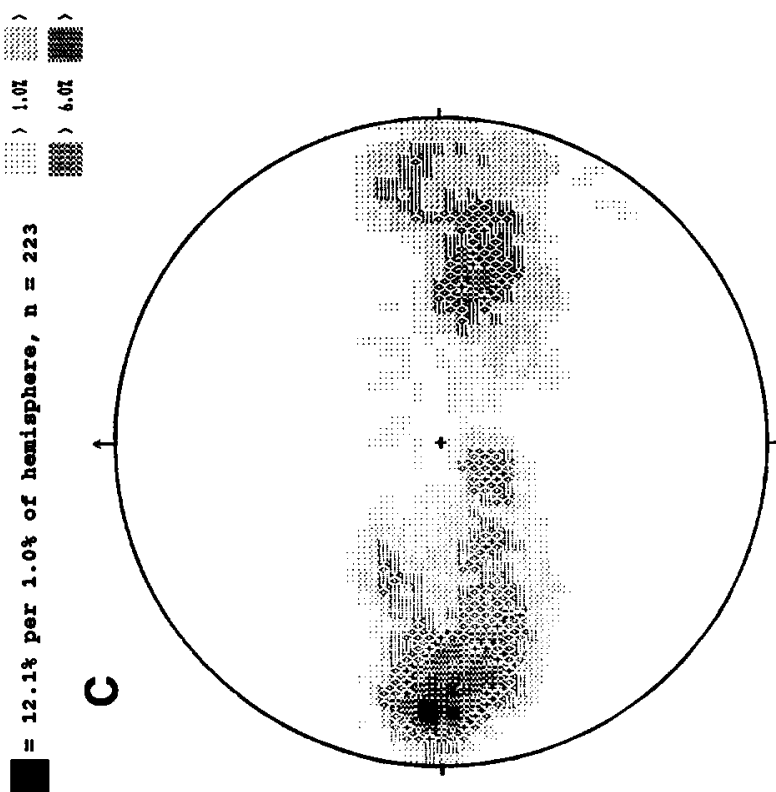

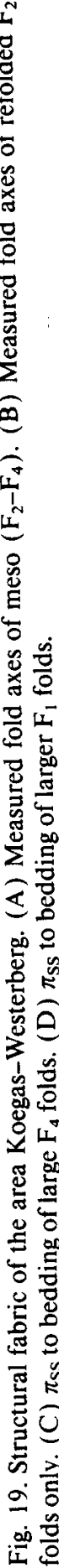




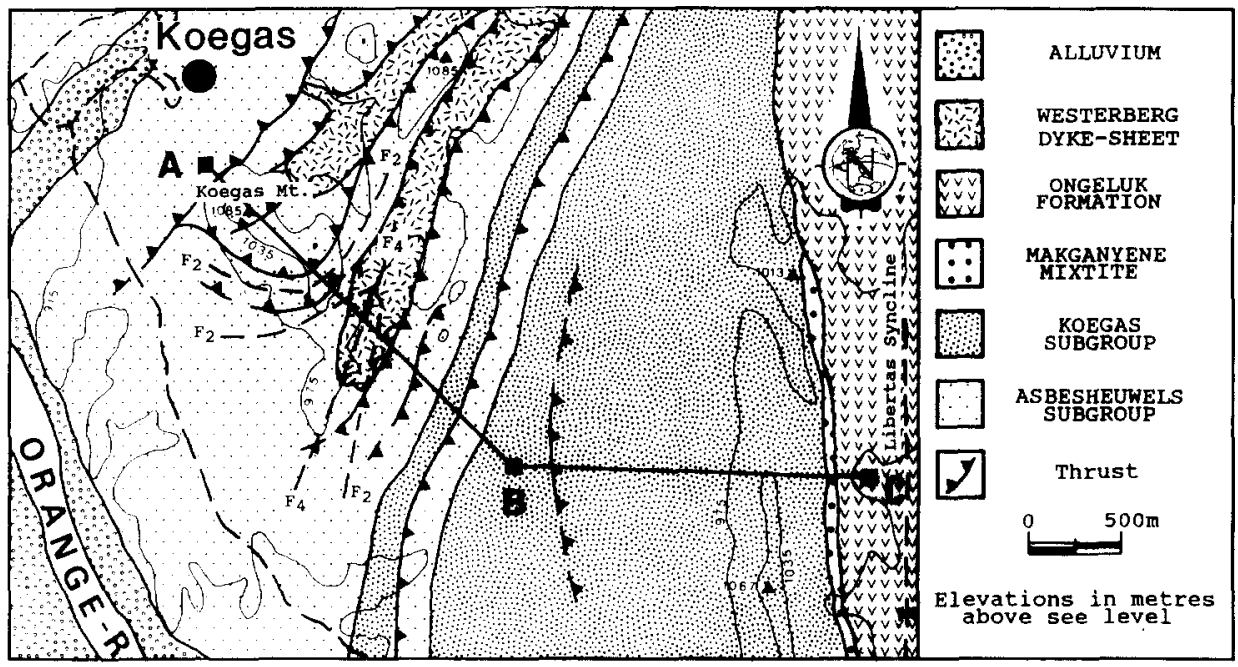

Fig. 20. The geology southeast of Koegas showing difference in style and intensity of $\mathrm{D}_{2}$ as controlled by lithology. For location see Fig. 7.

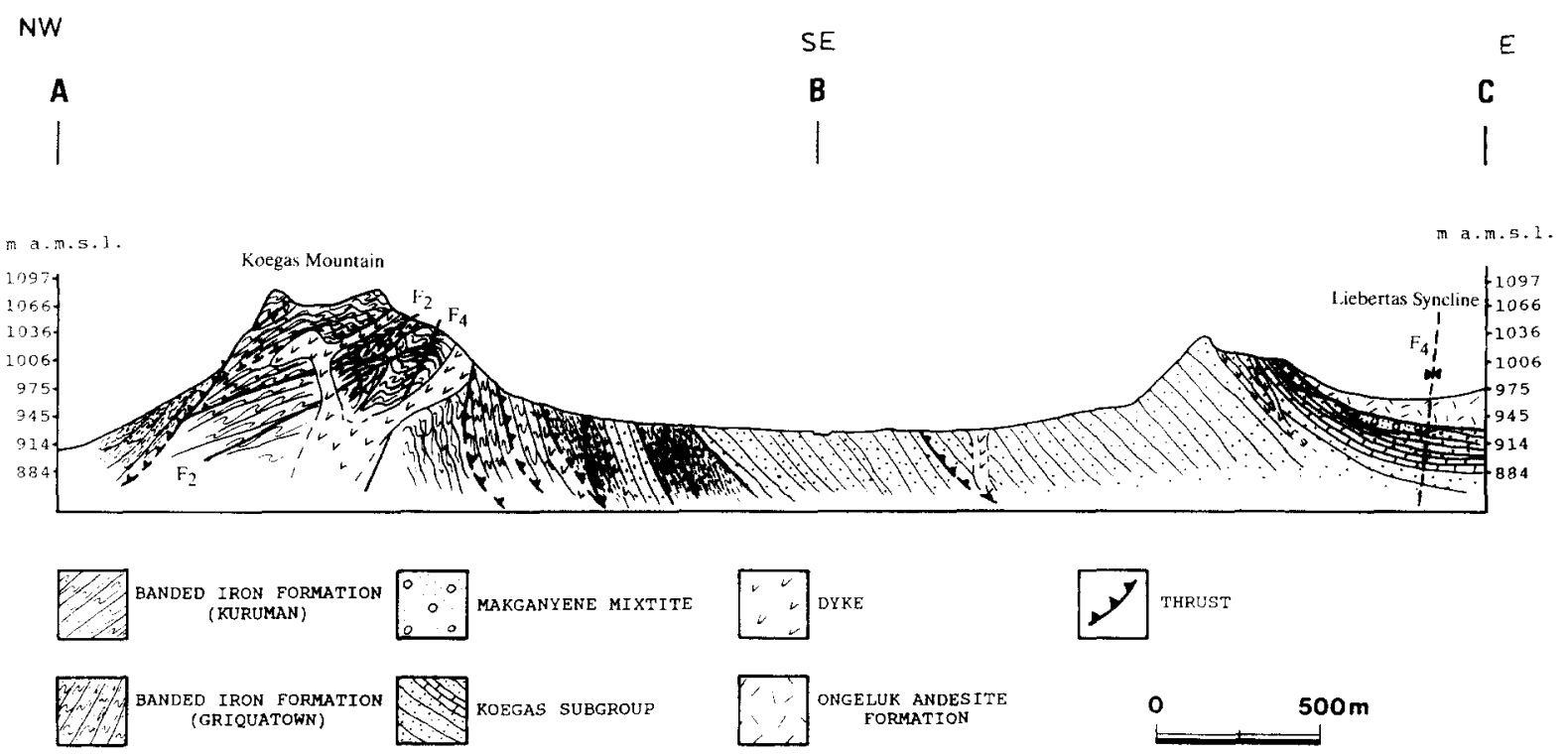

Fig. 21. Section A-B-C of Fig. 20. Note the difference in style of deformation between iron formation in Koegas Mountain and Koegas sediments to the east. Lithological duplication occurs along the eastern flank of Koegas Mountain, and the dips of $T_{2}$-thrusts vary across the mountain because of asymmetric E-vergent $F_{4}$ anticlinal refolding with a steep eastern limb.

long time-span could have separated the earlier from the later episodes because of the size of the pre-Makganyene high-angle unconformity.
$D_{3}$

The thrust below the Groot Witberg tectonic outlier of Matsap rocks could have happened 


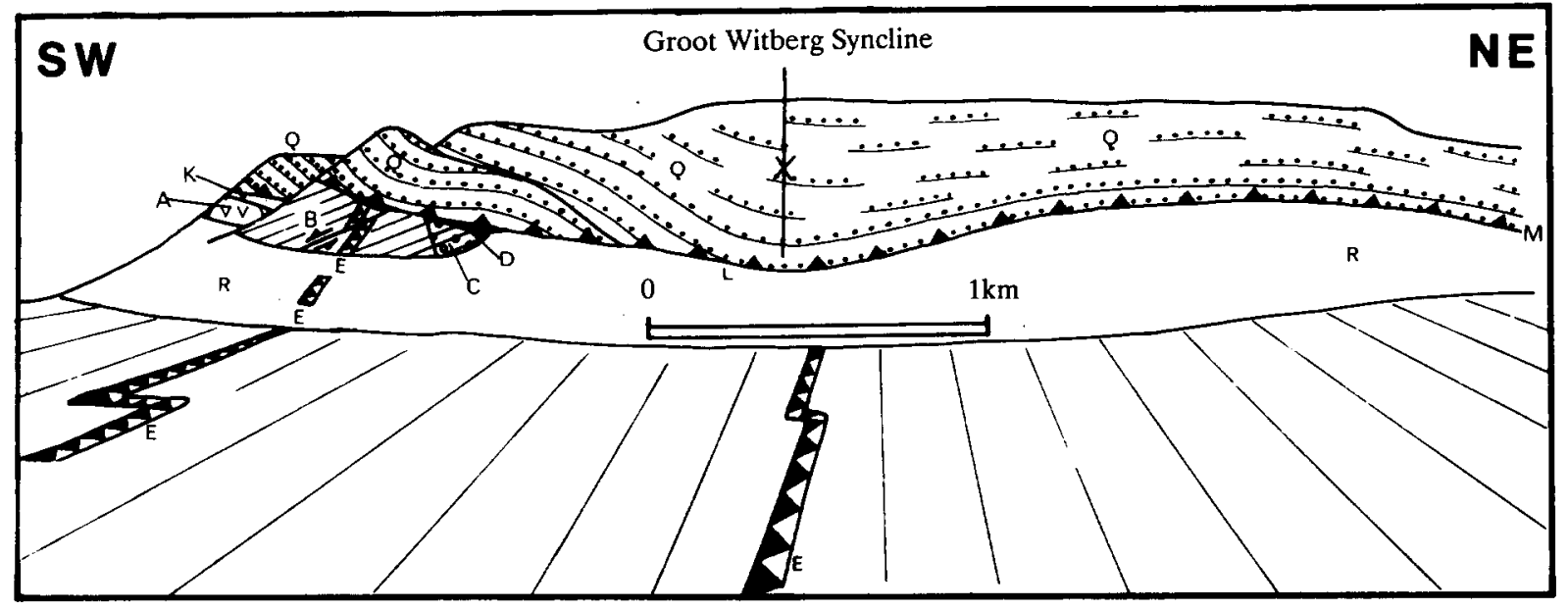

Fig. 22. Panoramic sketch of Groot Witberg Mountain looking north from near the dwelling on farm Grasgat (Fig. 17). The tectonic contact KDLM at the base of the Matsap $(Q)$ is folded by $F_{4}$, as are the Matsap beds themselves, to form the Groot Witberg syncline (Fig. 17). A=Ongeluk amygdaloidal lava. B=Koegas Subgroup of north striking siltstones and tectonically intercalated BIF, isoclinally folded and east-vergent. $\mathrm{C}=$ Makganyene mixtite. Both $\mathrm{B}$ and $\mathrm{C}$ are affected by a set of post $D_{1}$ and $D_{2}$ shear planes striking $N E$ and absent from Ongeluk and Matsap. $D=$ lenses of thrust fault breccia along contact to Matsap sediments. This breccia truncates both over and underlying beds. $E=$ bedding-parallel $D_{1}-D_{2}$ thrust breccia in Koegas. $R=$ scree. Time sequence: (1) folding and thrusting of Koegas Subgroup (B) during $D_{1}-D_{2} ;(2)$ erosion and deposition of Makganyene (C); (3) shearing of B and C; (4) erosion and deposition of Ongeluk (A) (2240 $\mathrm{Ma}) ;(5)$ erosion and deposition of Matsap $(Q) ;(6)$ emplacement of Matsap allochthone $\left(\mathrm{T}_{3}\right) ;(7) \mathrm{N}-\mathrm{S}\left(\mathrm{F}_{4}\right)$ folding of Matsap and $\mathbf{T}_{4}$ thrusting.
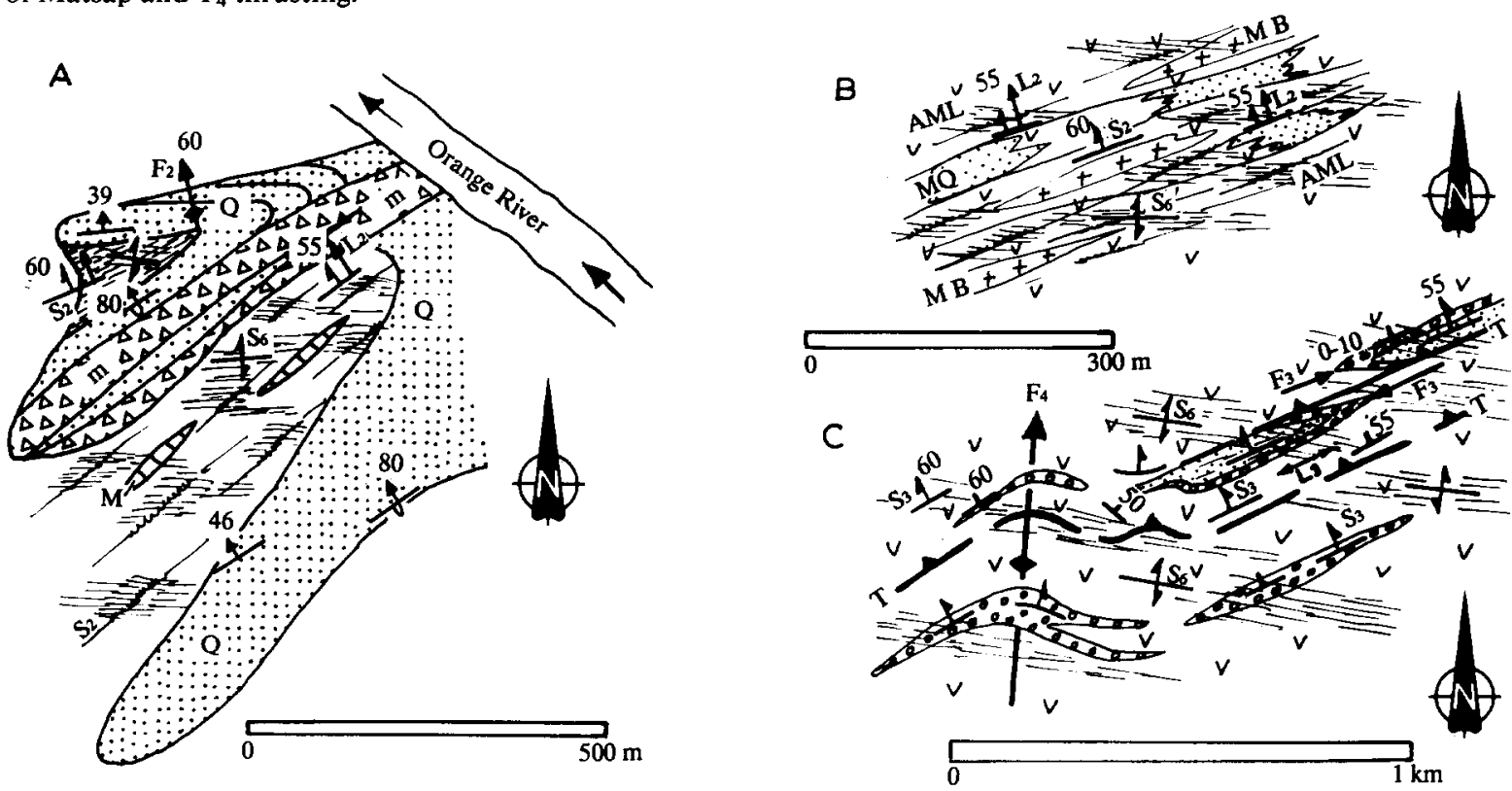

Fig. 23. Structural relationships in rocks west of the Orange River in Fig. 17. Note that $S_{6}$ has a constant attitude and is the youngest structure in all these outcrops. $F_{3}$ are not developed in strata older than Matsap beds and $F_{2}$ are not developed in Matsap strata. The decoupling thrust plane between Matsap and older strata is not exposed in this area. (A) On Seekoebaard 1, in Vryburg quartzites $(Q)$ and Zeekoebaart lava $(V) . M=$ lenses of marble; $m=$ thick quartzite mylonite. (B) On Seekoebaard 2, lenses of metabasites $(M B)$ and metaquartzites $(M Q)$ drift in sheared amygdaloidal meta-lava $(A M L)$. For (A) and (B), $\mathrm{S}_{2}$ is equivalent to Vajners (1974, pp. 104-105, fig. 10b) main schistosity in the Zeekoebaart Formation of pre-Matsap age. (C) Synclines of Matsap quartzites and conglomerates, overlying older meta-lavas north of Seekoebaard 2. 
late in the Kheis-Koranna orogeny (2.2-2.0 $\mathrm{Ga}$, Barton and Burger, 1983) but is more likely to be of post-Hartley lava age ( 2.07 to $1.88 \mathrm{Ga}$ ). $\mathrm{KF}_{1}$ and $\mathrm{NF}_{1 \mathrm{a}}$ (Table 2) from the Kheis and Gordonia subprovinces are comparable or somewhat younger in age. A somewhat younger $\mathrm{KF}_{2}$ and $\mathrm{NF}_{1 \mathrm{~b}}$ (Table 2) recorded by Stowe (1986) from these areas respectively have not been detected elsewhere around and on the craton. They must have had a restricted distribution due to specialized, local circumstances. Beukes and Smit (1987) suggested that the Blackridge Thrust Fault system is of Kheis-Koranna age. However, from their stratigraphic table it is evident that this system duplicates the Mapedi Formation and the conformable strata of the Olifantshoek Group, including the Hartley lavas, above it. Consequently, the Blackridge Thrust system is of post-Matsap age or younger than the $2070 \pm 90 \mathrm{Ma}(1881 \pm 57 \mathrm{Ma}$, Armstrong, 1987) of Hartley lava. Therefore, the Blackridge fault system of Beukes and Smit (1987) is probably $\mathrm{D}_{3}$-related (Table 2 ). The thrust below Groot Witberg described above seems to belong to this episode.

$D_{4}$

These N-S-trending upright and asymmetric E-vergent folds and associated minor brittle thrusts post-date the intrusion of the Westerberg dyke-sheet (e.g. the Witberg oblique fault, Fig. 17), and are associated with a steeply west-dipping cleavage. They deform the Groot Witberg klippe and the $D_{3}$-thrust and folded Matsap strata around Boegoeberg Dam. They also develop the most prominent $\mathrm{N}$-trending mega-anticlines and synclines in the Griqualand West sequence (Figs. 1, 7 and 17). The age of $\mathrm{D}_{4}$ structures is less than 2.07 to 1.88 $\mathrm{Ga}$. Some re-activation of $\mathrm{D}_{1}-\mathrm{D}_{2}$-structures may have occurred during this episode.

$D_{5}$

$\mathrm{D}_{5}$ structures comparable to the main $\mathrm{NF}_{2}$ Namaqua phase (Stowe, 1986) in the Uping- ton terrain (Fig. 1 and Table 2) are feebly developed in the Kheis Subprovince (Stowe, 1986 ) and do not occur on the Marydale High and east thereof probably because of effective shielding of a proto-Marydale High.

$D_{6}$

These very open E-W to ENE-WSW folds produce type (1) interference patterns (Ramsay, 1967) with $F_{4}$ and $F_{5}$ (Figs. 1 and 7 ). All the other subprovinces underwent a very similar late Namaqua folding (e.g. Graafwater synform, Harris, 1988, Table 2). It is estimated to be $1.1 \mathrm{Ga}$ old (Stowe, 1986).

$D_{7}$

The Doornberg Lineament is an oblique wrench fault with a transpression component transporting up in the SW, along the NW-SE Doornberg Fault Zone, and the Westerberg Fault is a very similar but right-lateral splay fault of lesser effect. The age is considered to be just less than 1.0 Ga (Stowe, 1986).

\section{Structural model}

An attempt has been made to combine the new evidence for mid-Early Proterozoic regional thrusting described here with well know regional fold structures of the $\mathrm{F}_{4}, \mathrm{~N}$-S-trending set, by assuming a sole thrust at the shale horizon of the Schmidtsdrif Subgroup (Fig. 24 ). From $15 \mathrm{~km}$ east of the Westerberg Fault the principle of balanced cross-sections (Dahlstrom, 1969; Woodward et al., 1989) has been applied for the construction. It appears that not more than about $25 \%$ of cumulative horizontal shortening has occurred by thrusting and homogeneous deformation (cleavage development, especially in riebeckite lutites during ramp climb) over about $100 \mathrm{~km}$ of section.

The westernmost part underwent considerable ductile deformation at amphibolite facies metamorphism. The diagram does not show the full extent of possible overriding of the 

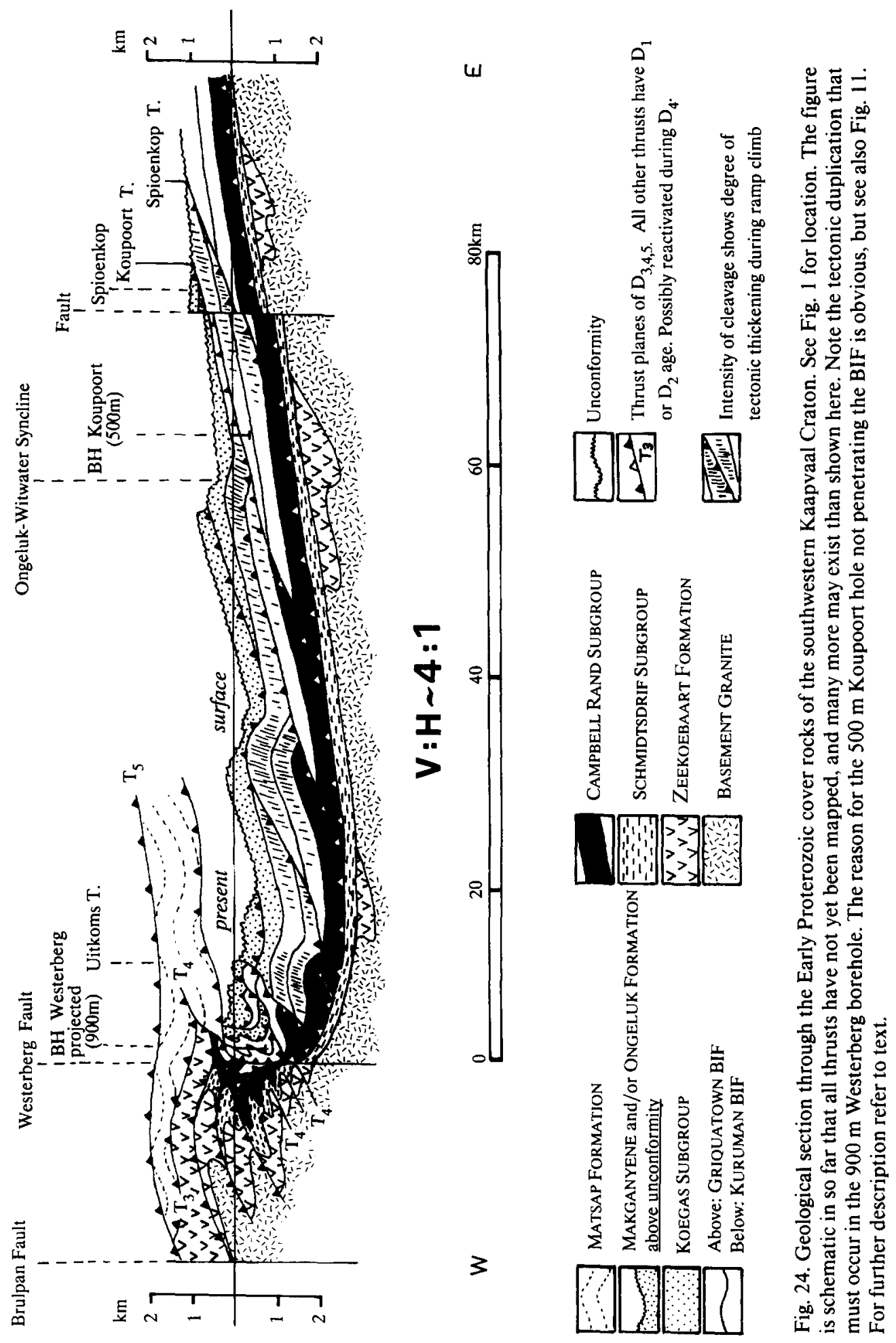
Zeekoebaart Formation and Marydale Granite onto the craton because of the younger $T_{3-}$ thrusts coming from the north and which probably follow a major post-Postmasburg preOlifantshoek erosion surface in this area.

Figure 24 implies that the Early Proterozoic $\mathrm{D}_{1}-\mathrm{D}_{2}$ deformations ( $>2240 \mathrm{Ma}$ and $<2432$ $\mathrm{Ma})$ have come from root zones on the Marydale High and beyond it to the west, where the Namaqua Province (deformed much later at high-grade metamorphism), is found today. The many macro-structures and the riebeckite mobilization along thrust zones of course can not be depicted on this scale. However, riebeckite mobilization is borne out by the following facts:

(i) Only riebeckite lutites developed a penetrative cleavage in folds in and above dislocation planes.

(ii) Selective solution along these cleavage planes supplies the necessary material to be transported into riebeckite halos that accompany many of the fold-thrust zones.

(iii) Riebeckite lutites are also physically the most mobile stratigraphic units, injected into and along thrust planes (Altermann and Hälbich, 1990).

(iv) Commercial quantities of crocidolite grow as secondary fibre across dilating tension fissures parallel to bedding planes. They concentrate in fold zones that are associated with thrusts and decollements.

(v) South of the Griquatown Fault, quartz is mobilized together with riebeckite, and tigers eye appears as a pseudomorphic replacement of crocidolite along slip- and transversefibre. North of the Griquatown Fault, crocidolite is not regularly replaced by $\mathrm{SiO}_{2}$.

\section{Conclusion}

Substantial evidence exists that duplication of Transvaal strata by complex thrust-faulting and -folding occurred all over the southwestern Kaapvaal Craton in Griqualand West. The thrust planes can be found at least $130 \mathrm{~km}$ away from the present craton margin (Figs. 1 and 24 ). Stowe (1986) found several phases of thin-skinned thrusting that developed from 1.75 Ga onwards in Middle Proterozoic rocks overlying the Kaapvaal Craton in the Kheis Subprovince. Because of competency differences, still older thrusts and folds have developed mainly in the Asbesheuwels but also in the Koegas Subgroups and the apparently simple lithological sequence (Beukes, 1980, 1983) actually represents a tectonically thickened and partly duplicated pile (Fig. 24). Stratigraphic thickness of various units that have so far been recorded from the western Kaapvaal Craton are therefore definitely overestimated, which has certainly led to some stratigraphic and environmental misinterpretations in the past. The treatment of this effect is beyond the scope of this paper.

If the Griquatown Fault (Fig. 1) is viewed in the light of tectonic complications reported here, it seems likely that further thickening of the stratigraphic column to the south of it was influenced by thrusting and decollement, possibly following an older growth fault.

\section{Acknowledgements}

We greatly appreciate the hospitality of the farmers in the region, but especially of D.J. Oosthuyzen and his family. Mr. S.D. Roos drew our attention to important outcrops and was always interested in the progress of our work. GEFCO permitted us to stay at Koegasbrug and the CSIR provided funds to undertake this research. We acknowledge fruitful discussions with C.W. Stowe. The help and advice of colleagues and friends at the Department of Geology, University of Stellenbosch is sincerely appreciated. Mrs. S. Smit very patiently prepared the various versions of this manuscript until completion.

\section{References}

Altermann, W. and Hälbich, I.W., 1990. Thrusting, folding, and stratigraphy of the Ghaap Group along the 
south-western margin of the Kaapvaal Craton. S. Afr. J. Geol., 93: 556-616.

Armstrong, R.A., 1987. Geochronological Studies on Archean and Proterozoic Formations of the Foreland of the Namaqua Front and Possible Correlations on the Kaapvaal Craton. Unpubl. Ph.D. thesis, University Witwatersrand, 274 pp.

Armstrong, R.A., Compston, W., Retief, E.A. and Welke, H.J., 1986. Ages and isotopic evolution of the Ventersdorp volcanics. Geocongress '86, Extended Abstracts, Geol. Soc. S. Afr. Johannesburg, pp. 89-92.

Barton, E.S. and Burger, A.J., 1983. Reconnaissance isotopic investigations in the Namaqua Mobile Belt and implications for Proterozoic crustal evolution-Upington Geotraverse. Spec. Publ. Geol. Soc. S. Afr., 10: 173-191.

Barton, E.S., Armstrong, R.A., Cornell, D.H. and Welke, H.J., 1986. Feasibility of total-rock $\mathrm{Pb}-\mathrm{Pb}$ dating of metamorphosed banded iron formation; the Marydale Group, southern Africa. Chem. Geol., 59: 255-271.

Beukes, N.J., 1980. Lithofacies and stratigraphy of the Kuruman and Griquatown Iron Formations, Northern Cape Province, South Africa. Trans. Geol. Soc. S. Afr., 83: 69-86.

Beukes, N.J., 1983. Paleoenvironmental setting of iron formations in the depositional basin of the Transvaal Supergroup, South Africa. In: A.F. Trendall and R.C. Morris (Editors), Iron- Formation: Facts and Problems. Developments in Precambrian Geology 6. Elsevier, Amsterdam, pp. 131-210.

Beukes, N.J. and Smit, C.A., 1987. New evidence for thrust faulting in Griqualand West, South Africa: implication for stratigraphy and the age of red beds. S. Afr. J. Geol., 90: 378-394.

Burger, A.J. and Coetzee, F.J., 1973. Radiometric age measurements on rocks from Southern Africa to the end of 1971. Bull. Geol. Surv. S. Afr., 58: 1-46.

Burger, A.J. and Potgieter, G.J.A., 1979. Note on U-Pb zircon ages from granitic rocks near Prieskapoort, northwest Cape. Trans. Geol. Soc. S. Afr., 82: 271-273.

Cilliers, J.J. le R., 1961. The Nature and Origin of Rocks of the Lower Griquatown Stage and the Associated Deposits of Amphibole Asbestos in the Northern Cape, with Special Reference to the Koegas-Prieska Area. Unpublished D.Sc. thesis, Univ. Pretoria, South Africa, $168 \mathrm{pp}$.

Clifford, T.N., 1970. The structural framework of Africa. In: T.N. Clifford and I.G. Gass (Editors), African Magmatism and Tectonics. Olivier and Boyd, London, pp. 1-26.

Cornell, D.H., 1975. Petrology of the Marydale Metabasites. Unpublished Ph.D. thesis, Cambridge University, Cambridge.

Cornell, D.H., 1977. A post-Transvaal age for the Marydale Formation, Kheis Group, southern Africa. Earth Planet. Sci. Lett., 37: 117-123.
Cornell, D.H. and Barton, E.S., 1979. Age of the Marydale Group banded iron formation by the PB-PB method. Abstr., 18th Geol. Congr., Geol. Soc. S. Afr., pp. 111-114.

Cornell, D.H., Hawkesworth, C.J., Van Calsteren, P. and Scott, W.D., 1986. Sm-Nd study of Precambrian crustal development in the Prieska-Copperton region, Cape Province. Trans. Geol. Soc. S. Afr., 89: 17-28.

Coward, M.P. and Potgieter, R., 1983. Thrust zones and shear zones of the margin of the Namaqua and Kheis mobile belts, southern Africa. Precambrian Res., 21: 39-54.

Dahlstrom, C.D.A., 1969. Balanced cross sections. Can. J. Earth Sci., 6: 743-757.

Du Plooy, C.L.W., 1986. Die Stratigrafie en Struktuur van die Asbesheuwel Formasie tussen Griekwastad en Niekerkshoop met Implikasies vir die Krokidoliet Genese. Unpublished M.Sc. thesis, University of Stellenbosch, $120 \mathrm{pp}$.

Du Toit, A.L., 1945. The origin of asbestos deposits of South Africa. Trans. Geol. Soc. S. Afr., 1: 71-75.

Fockema, P.D., 1967. Crocidolite and Associated Rocks of the Kuruman Area in the Northern Cape. Unpublished Ph.D. thesis, Univ. Witwatersrand, Johannesburg, 189 pp.

Hanekom, H.J., 1966. The Crocidolite Deposits of the Northern Cape Province. Unpublished D.Sc. thesis, Univ. Pretoria, 213 pp.

Harris, R.W., 1988. Examination of dextral transpression as a model for the development of thrusts and late folds in eastern Namaqualand. S. Afr. J. Geol., 91: 324-336.

Humphreys, H.C., van Schalkwyk, L. and Scott, W.D., 1986. A geological and structural map of the Areachab Group succession at Prieska Copper Mines, northwest Cape Province. S. Afr. J. Geol., 91 (3): 373-380.

Humphreys, H.C., van Bever Donker, J.M., Scott, W.D. and van Schalkwyk, L., 1988. The early deformational history of the eastern Namaqua Province: new evidence from Prieska Copper Mines. S. Afr. J. Geol., 91 (2): 174-183.

Jahn, B., Bertrand-Sarfati, J., Morin, N. and Mace, J., 1990. Direct dating of stromatolitic carbonates from the Schmidtsdrif Formation (Transvaal Dolomite), South Africa, with implications on the age of the Ventersdorp Supergroup. Geology, 18: 1211-1214.

Moen, H.G.F., 1976. A Geological Investigation of an Area North of Groblershoop, Northern Cape Province with Special Reference to the Wilgenhoutdrift Formation. Unpubl. Rep., Geol. Surv. South Africa.

Moody, J.D. and Hill, M.J., 1956. Wrench-fault tectonics. Geol. Soc. Am. Bull., 67: 1207-1246.

Onstott, T.C., Hargraves, R.B. and Joubert, P., 1986. Constraints on the tectonic evolution of the Namaqua Province III: Reconnaissance Paleomagnetic and ${ }^{40} \mathrm{Ar} /$ ${ }^{39} \mathrm{Ar}$ results from the Namaqua Province and Kheis Belt. Trans. Geol. Soc. S. Afr., 89: 143-170. 
Potgieter, G.J.A., 1981. Die Litostratigrafie en Strukturele Aspekte van die Suidwestelike Rand van die Kaapvaal-Kraton, Wes van Prieska, Noord Kaapland. Unpublished Ph.D. thesis, University of the Orange Free State, 242 pp.

Ramsay, J.G., 1967. Folding and Fracturing of Rocks. McGraw-Hill, New York, N.Y., 568 pp.

Rogers, A.W. and Du Toit, A.L., 1909. Report on Geology of Parts of Prieska, Hay, Bristown, Carnavon, and Victoria West. Annu. Rep. 1908, Geol. Comm. Cape Colony. Longmans Green and Co., London, $491 \mathrm{pp}$.

SACS-South African Committee for Stratigraphy, 1980. Stratigraphy of South Africa, Part 1 (Comp. L.E. Kent ). Lithostratigraphy of the Republic of South Africa, South West Africa/Namibia, and the Republics of Bophuthatswana, Transkei and Venda. Handbook Geol. Surv. S. Afr., 8, 690 pp.

Scott, W.D., 1987. A Lithostratigraphic and Metamorphic Profile Across the Kaapvaal-Namaqua Boundary North-west Cape Province. Unpublished M.Sc. thesis, University of Stellenbosch, Stellenbosch, $215 \mathrm{pp}$.

Stowe, C.W., 1983. The Upington geotraverse and its implication for craton margin tectonics. In: B.J.V. Botha (Editor), Namaqualand Metamorphic Complex. Spec. Publ., Geol. Soc. S. Afr., 10: 147-172.

Stowe, C.W., 1986. Synthesis and interpretation of structures along the north-eastern boundary of the Namaqua tectonic province, South Africa. Trans. Geol. Soc. S. Afr., 89: 185-189.

Tankard, A.J., Jackson, M.P.A., Eriksson, K.A., Hobday, D.K., Hunter, D.R. and Minter, W.E.L., 1982. Crustal
Evolution of Southern Africa. Springer Verlag, New York, N.Y., $523 \mathrm{pp}$.

Theart, N.F.J., 1985. Copperton-Areachap Cu-Zn Mineralization. Ph.D. thesis (unpublished), University of Stellenbosch, Stellenbosch, 329 pp.

Trendall, A.F., Compston, W., Williams, I.S., Armstrong. R.A., Arndt, N.T., McNaughton, N.J., Nelson, D.R., Barley, M.E., Beukes, N.J., Laeter, J.R.de, Retief, E.A. and Thorne, A.M., 1990. Precise zircon U-Pb chronological comparison of the volcano-sedimentary sequences of the Kaapvaal and Pilbara cratons between about 3.1 and 2.4 Ga. 3rd Int. Archean Symposium, Perth, 1990, Extended Abstracts, pp. 81-83.

Vajner, V., 1974a. The Tectonic Development of the Namaqua Mobile Belt and its Foreland in Parts of the Northern Cape. PRU Bull. 14, University of Cape Town, $201 \mathrm{pp}$.

Vajner, V., 1974b. The Doringberg Fault and its relation to the post-Waterberg deformation. Trans. Geol. Soc. S. Afr., 77: 295-300.

Visser, D.J.L., 1944. Stratigraphic features and tectonics of portions of Bechuanaland and Griqualand West. Trans. Geol. Soc. S. Afr., 47: 197-254.

Walraven, F., Burger, A.J. and Allsopp, H.L., 1982. Summary of age determinations carried out during the period April 1980 to March 1981. Ann. Geol. Surv. S. Afr., 16: 107-114.

Woodward, N.B., Boyer, S.E. and Suppe, J., 1989. Balanced Geological Cross-Sections: An Essential Technique in Geological Research and Exploration. Short course in geology, Am. Geophys. Union, Washington, D.C., 132 pp. 